OECDpublishing

PUBLIC FINANCE STRUCTURE AND INCLUSIVE GROWTH

OECD ECONOMIC POLICY PAPER

December 2018 No. 25 
Economic Policy Paper No. 25

\title{
Public finance structure and inclusive growth
}

This paper has been prepared by:

\author{
Boris Cournède \\ Jean-Marc Fournier \\ Peter Hoeller
}

Authorised for publication by Laurence Boone Chief Economist and G20 Finance Deputy 
The OECD Economic Policy Paper Series is published on the responsibility of the Secretary General of the OECD. The opinions expressed and arguments employed herein do not necessarily reflect the official views of the Organisation or of the governments of its member countries.

Series: OECD Economic Policy Papers

ISNN:2226583X

The statistical data for Israel are supplied by and under the responsibility of the relevant Israeli authorities. The use of such data by the OECD is without prejudice to the status of the Golan Heights, East Jerusalem and Israeli settlements in the West Bank under the terms of international law.

On 3 May 2018, the OECD Council invited Lithuania to become a Member. At the time of preparation, the deposit of Lithuania's instrument of accession to the OECD Convention was pending and therefore Lithuania does not appear in the list of OECD Members and is not included in the OECD zone aggregates.

On 25 May 2018, the OECD Council invited Colombia to become a Member. At the time of preparation, the deposit of Colombia's instrument of accession to the OECD Convention was pending and therefore Colombia does not appear in the list of OECD Members and is not included in the OECD zone aggregates.

This document and any map included herein are without prejudice to the status of or sovereignty over any territory, to the delimitation of international frontiers and boundaries and to the name of any territory, city or area

(C) OECD 2018

You can copy, download or print OECD content for your own use, and you can include excerpts from OECD publications, databases and multimedia products in your own documents, presentations, blogs, websites and teaching materials, provided that suitable acknowledgment of OECD as source and copyright owner is given. All requests for public or commercial use and translation rights should be submitted to rights@oecd.org. Requests for permission to photocopy portions of this material for public or commercial use shall be addressed directly to the Copyright Clearance Center (CCC) at info@copyright.com or the Centre français d'exploitation du droit de copie (CFC) at contact@cfcopies.com 
An earlier version of this paper was discussed by the OECD Economic Policy Committee. The authors would like to thank the participants for their feedback. They are grateful to Åsa Johansson, who led the project during its first stage. They are also indebted to Laurence Boone, Bert Brys, Robert Hagemann, Christine Lewis, Luiz de Mello, Dorothée Rouzet, and Alain de Serres for their comments and Celia Rutkoski for outstanding editorial assistance.

The authors dedicate their work to the memory of Mrs. Debra Bloch, who passed away in August 2018. Her remarkable statistical work has provided the data foundation for this study.

More detailed information is available in the following publications:

Akgun, O., D. Bartolini and B. Cournède (2017), "The Capacity of Governments to Raise Taxes", OECD Economics Department Working Papers, No. 1407, OECD Publishing, Paris, http://dx.doi.org/10.1787/6bee2df9-en.

Akgun, O., B. Cournède and J. Fournier (2017), "Effects of the Tax Mix on Inequality and Growth", OECD Economics Department Working Papers, No. 1447, OECD Publishing, Paris, http://dx.doi.org/10.1787/c57eaa14-en.

Bloch, D., J.M. Fournier, D. Gonçalves and A. Pina (2016), "Trends in Public Finance: Insights from a New Detailed Dataset," OECD Economics Department Working Papers, No. 1345, https://doi.org/10.1787/4d3d8b25-en

Fournier, J. (2016), "The Positive Effect of Public Investment on Potential Growth”, OECD Economics Department Working Papers, No. 1347, OECD Publishing, Paris, http://dx.doi.org/10.1787/15e400d4en.

Fournier, J. and A. Johansson (2016), "The Effect of the Size and the Mix of Public Spending on Growth and Inequality", OECD Economics Department Working Papers, No. 1344, OECD Publishing, Paris, http://dx.doi.org/10.1787/f99f6b36-en.

Johansson, A. (2016), "Public Finance, Economic Growth and Inequality: A Survey of the Evidence", OECD Economics Department Working Papers, No. 1346, OECD Publishing, Paris,

http://dx.doi.org/10.1787/094bdaa5-en. 


\section{Table of contents}

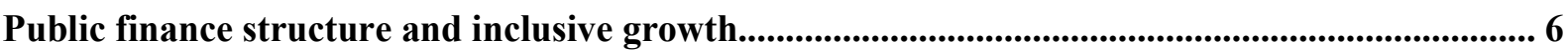

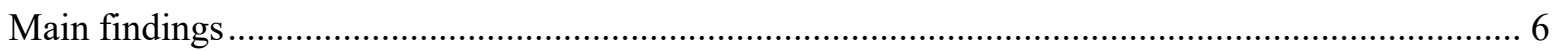

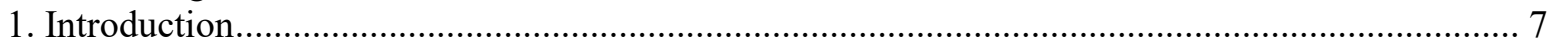

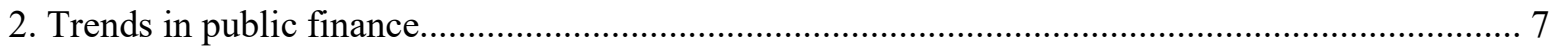

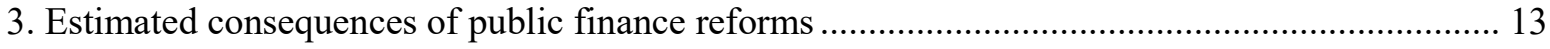

3.1. Areas with reform potential for higher and more equitably distributed incomes.................... 14

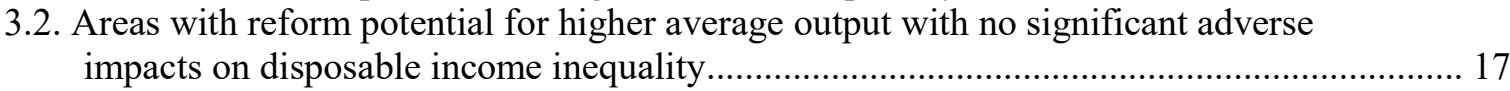

3.3. Areas with distributional income implications but no significant average output effect ......... 21

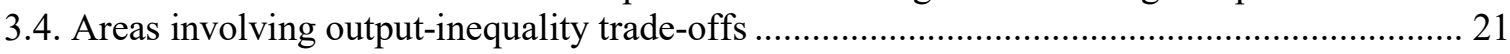

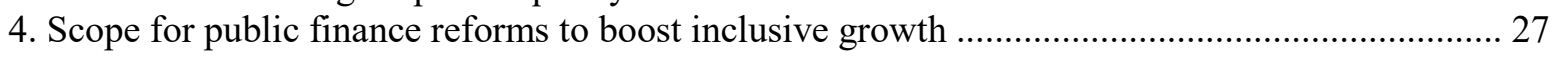

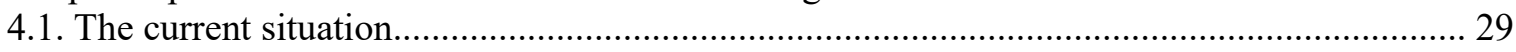

4.2. Two examples illustrating how the framework can be used to quantify public finance shifts 31

Annex A. Supplementary information on the analytical framework .............................................. 35

Annex B. Data coverage .......................................................................................................................................... 38

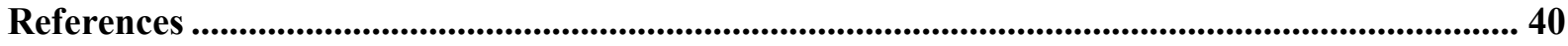

\section{Tables}

Table 1. Summary of estimated effects of public finance reforms on inequality and output........... 28

Table B.1. Country and time coverage of main spending variables in the empirical analysis............... 38

Table B.2. Country and time coverage of main tax variables in the empirical analysis ....................... 39 


\section{Figures}

Figure 1. Governments have expanded while changing their spending and revenue mixes................ 8

Figure 2. Large differences in spending structures separate OECD governments ............................ 10

Figure 3. Tax structures also vary considerably across OECD countries ........................................... 11

Figure 4. Two country examples illustrate changes over the past two decades.................................. 12

Figure 5. Moving the tax burden away from low-wage earners improves incomes for all ............... 15

Figure 6. Shifting the tax mix towards inheritance taxes enhances average income and makes its

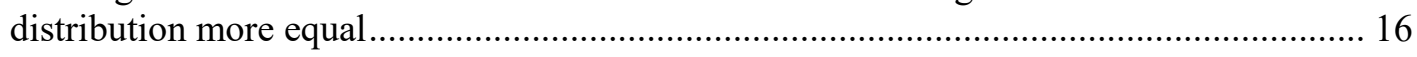

Figure 7. Many public finance shifts can boost average output with no adverse consequences for

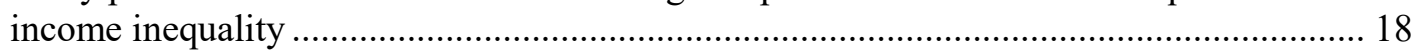

Figure 8. Reducing government size typically involves a trade-off between growth and equality but still increases incomes for most............................................................................... 22

Figure 9. Reducing government size increases incomes for all in countries with low perceived

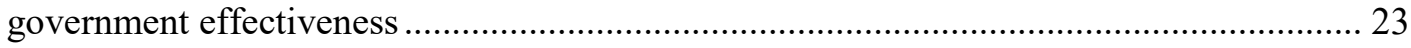

Figure 10. Reducing public subsidies improves average output but only boosts incomes at the top

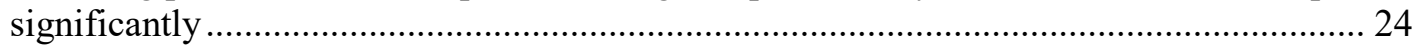

Figure 11. Reducing taxes on net wealth predominantly benefits the rich but raises

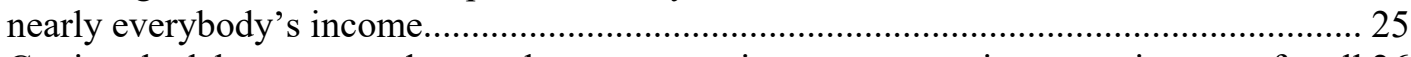

Figure 12. Cutting the labour tax wedge on above-average income earners improves incomes for all 26

Figure 13. Many countries have little room for raising standard VAT rates ....................................... 27

Figure 14. The estimated effects of public finance size and structure on output per capita vary considerably across OECD countries .............................................................................. 29

Figure 15. The effects of public finance on disposable income vary across income categories........... 30

Figure 16. Easing the labour tax wedge on below-average earnings funded by a cut in subsidies can boost incomes across the distribution............................................................................. 32

Figure 17. Relatively limited resources can fund large cuts in the effective rate of the labour tax wedge on below-average earnings in countries close to the revenue-maximising point..... 33

Figure 18. Shifting taxation away from low-paid labour towards environmental taxes can generate economic and distributional benefits in addition to improving the environment

\section{Box}

Box 1. Framework for the analysis 


\section{Public finance structure and inclusive growth}

\section{Main findings}

- Tax and spending reforms can promote inclusive growth in a number of ways. There is potential for win-win reforms that boost output and enhance income equality at the same time. Other changes in the public finance structure can produce benefits only along a single dimension, while some involve trade-offs between average income gains and distributional effects.

- The empirical work, which covers the experiences of OECD countries over the past three decades, evaluates how changes in revenue and spending structures influence long-term output per capita and the distribution of household disposable income. Findings from earlier OECD research that permanent changes in output per capita imply same-sized long-term changes in average household disposable income allow combining the output and inequality estimates to simulate how public finance reforms can change the level of disposable income for different income groups.

- The main findings from the OECD and other research are:

- Changes in the revenue mix that reduce the tax wedge on low-income earners and raise inheritance taxes generally improve output per capita and narrow the disposable income distribution.

- A number of reforms that shift spending and taxes while keeping overall government expenditure and revenue constant (through proportional adjustments in other items) offer potential to boost output per capita without significantly affecting the disposable income distribution, thus benefiting all. These include:

- Higher public investment,

- Higher recurrent property taxes,

- Lower effective rates of corporate income tax.

- Higher family and child allowances generally benefit the poor with no substantial effect on average output.

- A number of public finance reforms can improve average output at the cost of a wider income dispersion, but the output effects typically dominate so that absolute incomes increase for nearly all:

- Reducing public spending, except where governments are very effective, in which case there is no clear case for downsizing it,

- Lowering public subsidies,

- Lowering wealth taxes,

- Lowering the labour tax wedge on above-average income earners.

- There are limits to the reallocation of the tax burden from more towards less distortive taxes such as value-added taxes. Many European countries seem close to the point where higher rates lower revenue by generating large economic distortions and strong disincentives for compliance. Broadening the tax base and improving collection should be favoured instead. 


\section{Introduction}

Government spending makes up nearly two fifths of what OECD economies produce. The large resources governments collect from people and firms and then transfer, spend or invest shape the productive capacity of an economy and the distribution of income. The OECD project on the Quality of Public Finance has been investigating how the structure of the public finances influences output per capita and income distribution. This inquiry looks at the long-term effects of permanent changes in the public finances: it abstracts from considerations about how fiscal policy can help manage the business cycle.

The present report takes stock of the key findings of the OECD project on the Quality of Public Finance. A set of companion papers provide additional information, starting with a review of the literature about the long-term growth and inequality effects of public finance (Johansson, 2016 ${ }_{[1]}$ ). A dataset of internationally comparable information on public finance structure has been specially assembled and documented (Bloch et al., $\left.2016_{[2]}\right)$. Empirical investigations have analysed how the size and structure of government spending influence growth and inequality (Fournier and Johansson, 2016 $6_{[3]}$ ) with a focus on the role of investment (Fournier, 2016 $6_{[4]}$ ). Econometric studies have examined what drives the capacity of governments to raise taxes (Akgun, Bartolini and Cournède, $2017_{[5]}$ ) and how taxes influence the long-term level and distribution of income (Akgun, Cournède and Fournier, 2017 $[6]$ ). Recent OECD work has also considered how to design tax systems for inclusive growth (Brys et al., 2016 $[7]$ ) and what drives the redistributive capacity of tax and transfer systems (Causa and Hermansen, 2017 ${ }_{[8]}$; Causa and Akgun, 2018 [9]).

The next section of this report provides a broad-brush picture of public finance trends across OECD countries. Section 3 presents the main results, discusses how the estimated effects relate to the broader economic literature and highlights where they are most robustly identified and economically relevant. Section 4 uses these results to show the overall implications of countries' spending and tax structures on average output and the distribution of income before presenting quantitative simulations of hypothetical publicfinance reforms.

\section{Trends in public finance}

OECD governments have expanded in size since the turn of the century (Figure 1, Panel A). Measures adjusting for cyclical effects indicate that spending rose mostly in the precrisis period. Most of the increase occurred in the areas of health and pensions. Population ageing translated into greater public pension spending, though earlier reforms contained this expansion. The rise of health expenditure reflects the impact of ageing but also of other factors, such as the rising prices of treatments relative to other goods and services (de la Maisonneuve and Oliveira Martins, 2014 $[10]$ ).

By contrast, the post-crisis period has been characterised by roughly stable spending relative to GDP on average across OECD countries when adjusting for cyclical effects. This overall stability masks an acceleration in the rise of pension spending as large numbers of baby boomers retired, which was at least in part offset by cuts, relative to GDP, in other areas, especially public investment (Figure 1, Panel A). 
Figure 1. Governments have expanded while changing their spending and revenue mixes

Panel A. Cyclically-adjusted primary spending

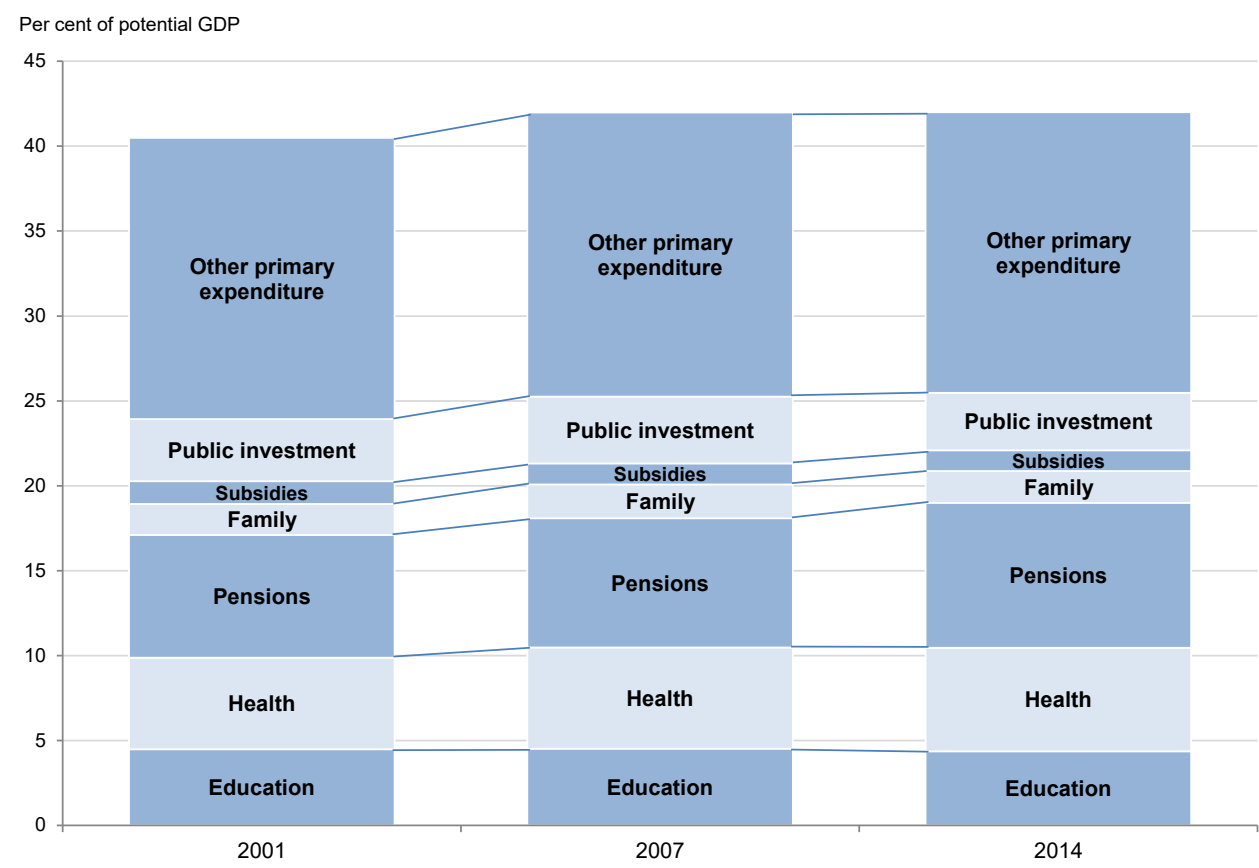

Panel B. Cyclically adjusted primary receipts

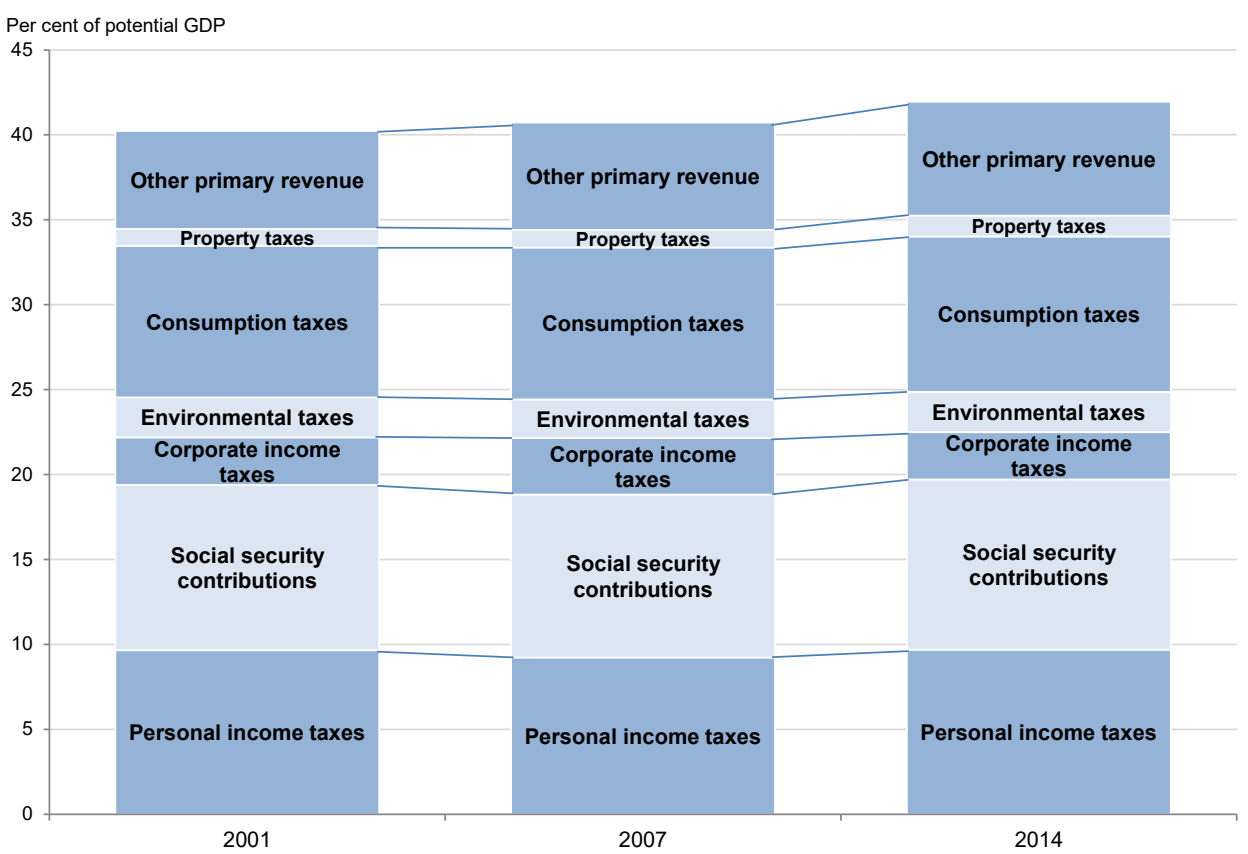

Note: Unweighted average of OECD countries for which data are available. The figure shows cyclically-adjusted spending and revenue items.

Source: OECD Public Finance Dataset (Bloch et al., 2016 $[2]$ ); OECD Economic Outlook No. 102 (Edition 2017/2) database (OECD, 2017 $[11]$ ). 
Government revenue increased moderately in the early and mid-2000s, after correcting for the impact of the cycle (Figure 1, Panel B). It has expanded more quickly since the crisis, as a number of governments came under pressure to keep public debt in check. This increase in government revenues has been accompanied by a change in their mix, with reduced receipts, relative to GDP, from corporate income taxes and increased reliance on personal income taxes, social security contributions and consumption taxes.

OECD countries have quite dissimilar spending structures (Figures 2 and 3) but have largely come under similar pressures and often undergone comparable changes. For instance, despite their very different spending and tax structures, the United States and the Netherlands both experienced strong increases in the share of health care in public spending and moderate shrinkage in the share of revenue coming from the corporate income tax (Figure 4). There were some noticeable differences, however, such as for public investment, the share of which shrank markedly in the United States but remained roughly constant in the Netherlands. 
Figure 2. Large differences in spending structures separate OECD governments

2012-14 averages, in per cent of GDP

Panel A. Education spending

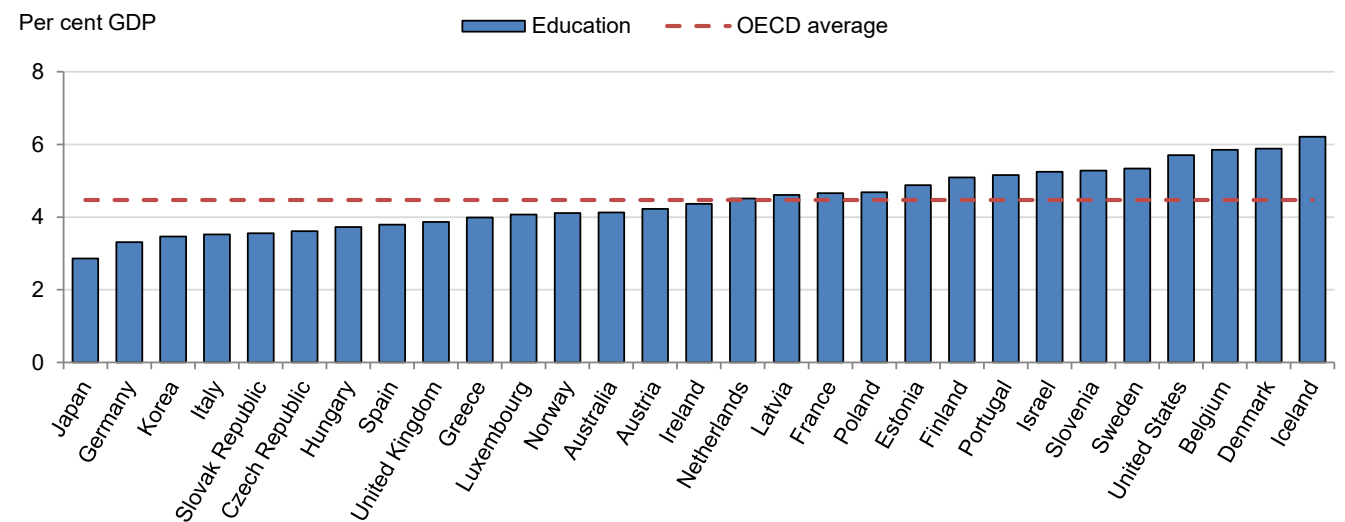

Panel B. Health spending

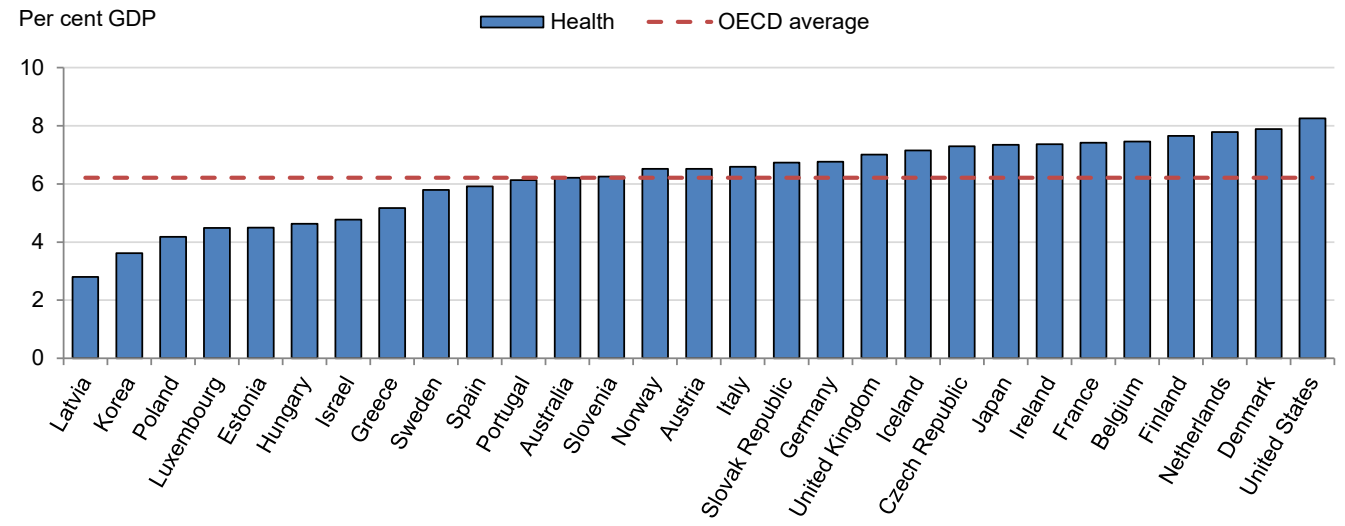

Panel C. Public investment

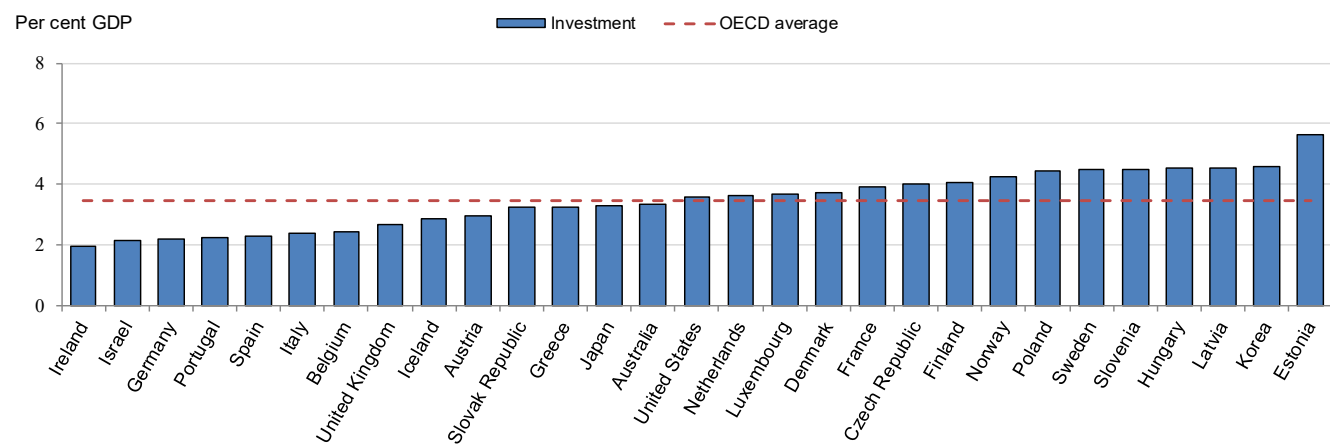

Note: Data refer to the average over the period 2012-14. The OECD average is the unweighted average of the countries shown in the figure.

Source: OECD Public Finance Dataset (Bloch et al., 2016 $6_{[2]}$ ); OECD Economic Outlook No. 102 (Edition 2017/2) database (OECD, 2017 $[11]$ ).

StatLink त्ञाS http://dx.doi.org/10.1787/888933887576 


\section{Figure 3. Tax structures also vary considerably across OECD countries}

2012-14 averages, in per cent of GDP

Panel A. Personal income tax and social security contributions

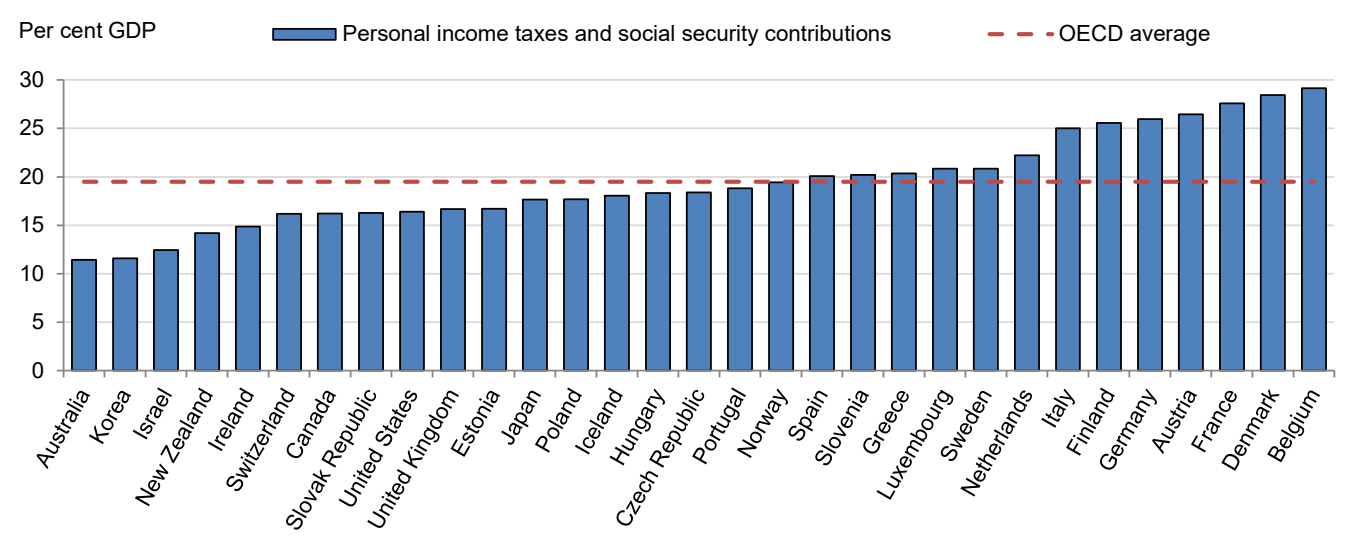

Panel B. Corporate income tax

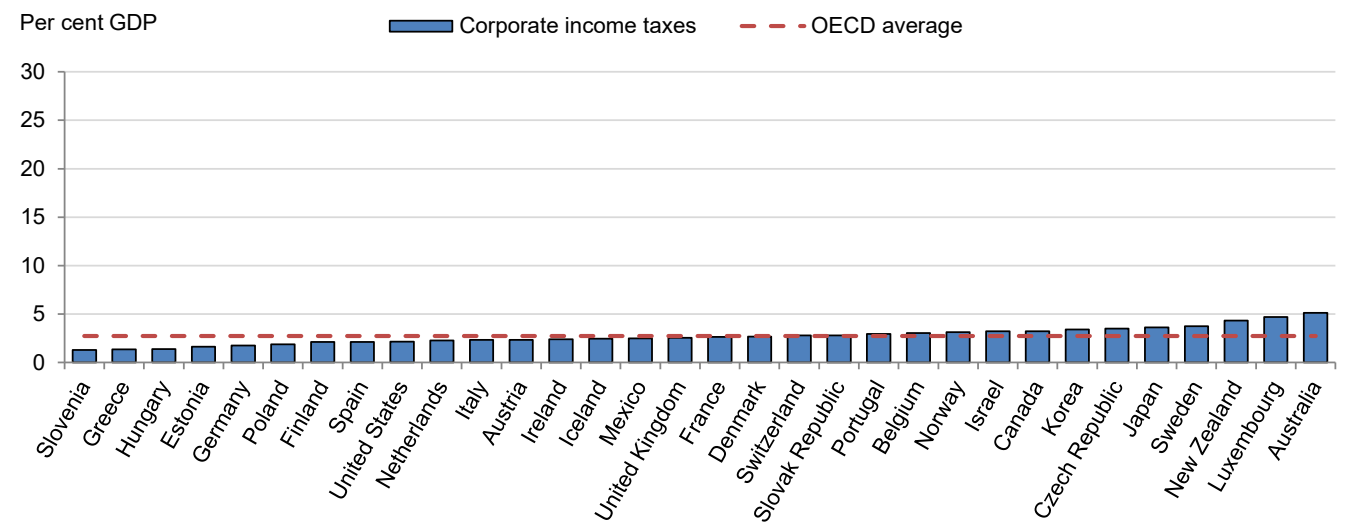

Panel C. Consumption taxes

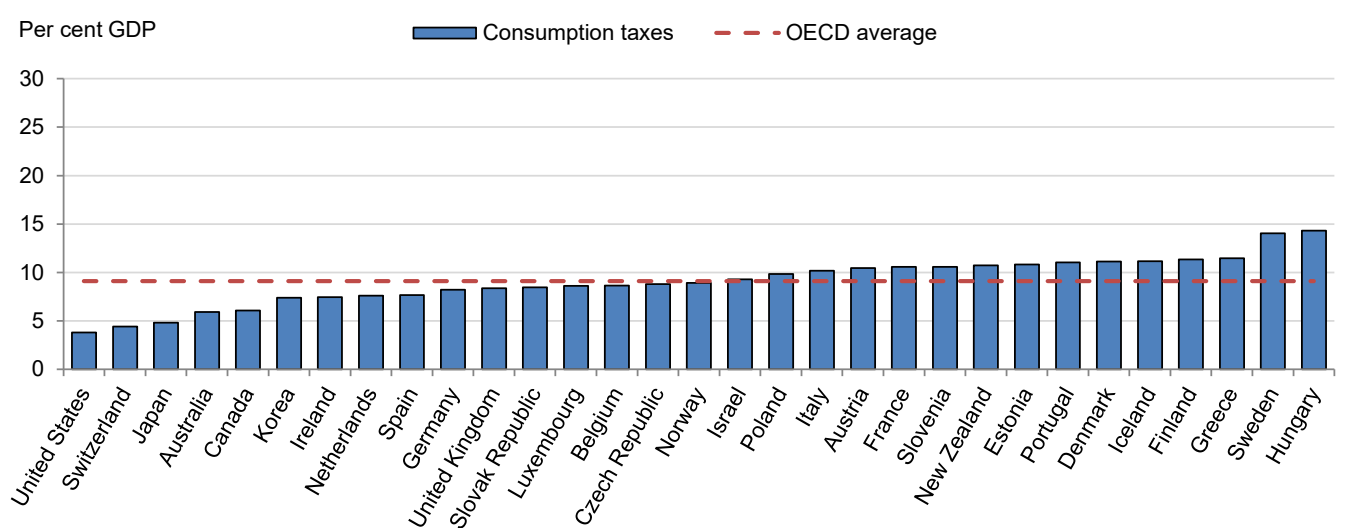

Note: Data refer to the average over the period 2012-14. The OECD average is the unweighted average of the countries shown in the figure.

Source: OECD Public Finance Dataset (Bloch et al., 2016 $\left.{ }_{[2]}\right]$; OECD Economic Outlook No. 102 (Edition 2017/2) database (OECD, 2017 [11]).

StatLink 제내 http://dx.doi.org/10.1787/888933887595 
Figure 4. Two country examples illustrate changes over the past two decades

1995 (inner circles) and 2014 (outer circles)

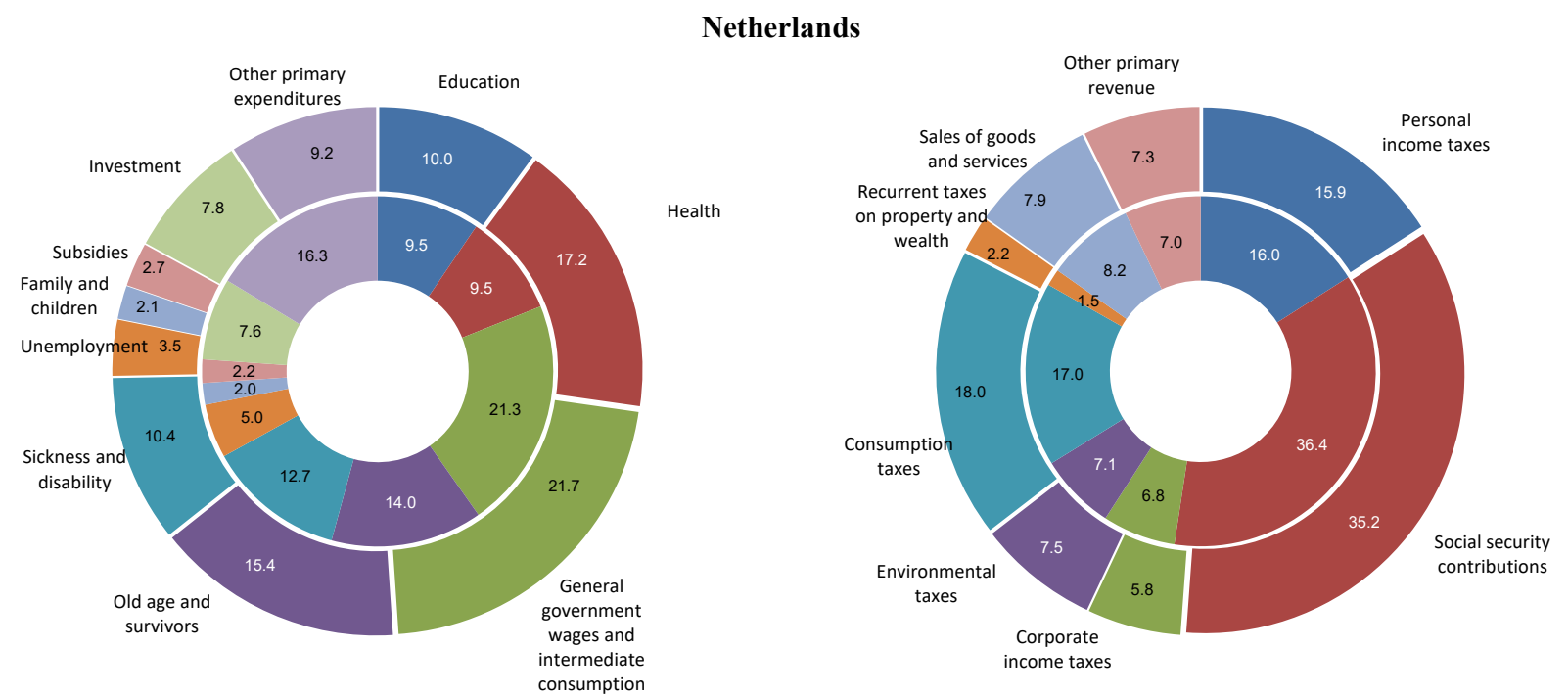

United States
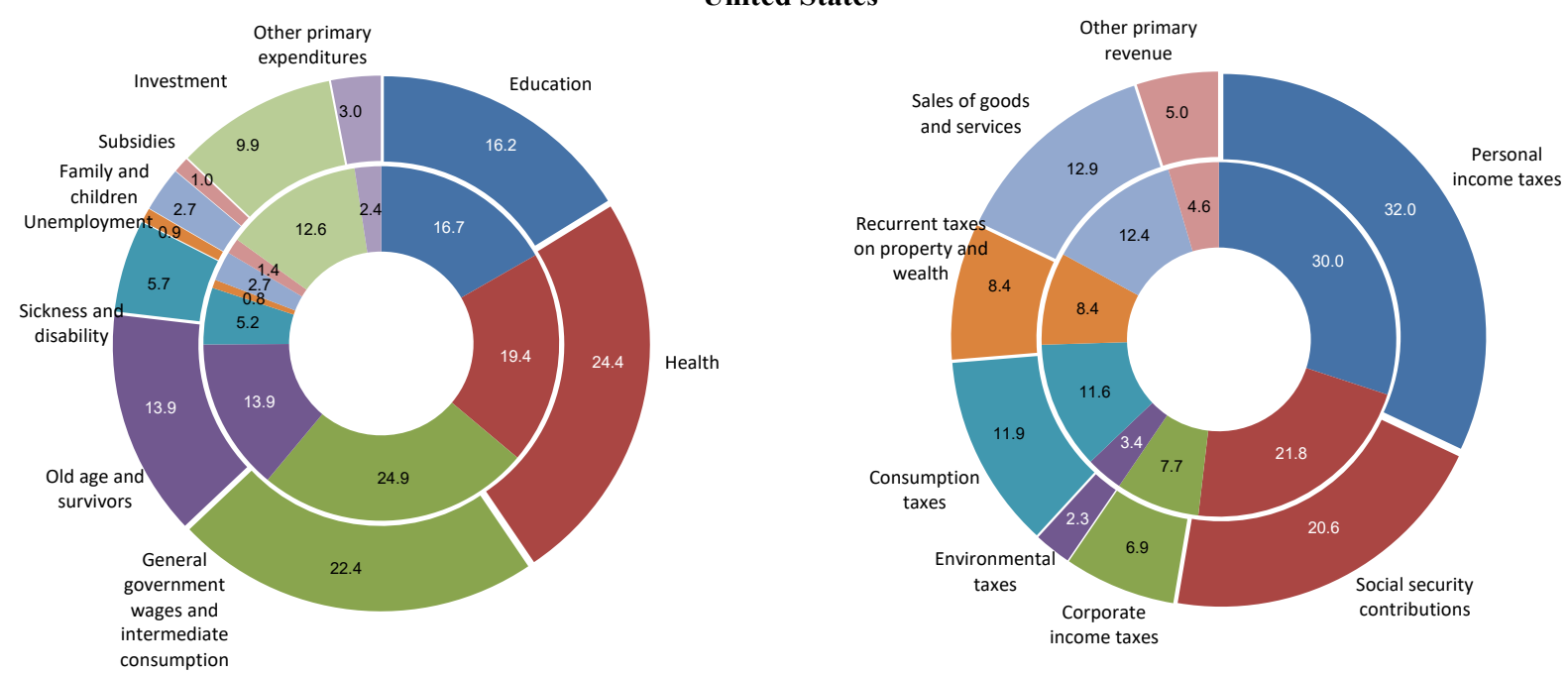

Note: The inner circles refer to 1995, while the outer circles to 2014 (data refer to 2013 for the United States for old age and survivors, sickness and disability, unemployment and family and children).

Source: OECD Public Finance Dataset (Bloch et al., 2016 ${ }_{[2]}$; OECD Economic Outlook No. 102 (Edition 2017/2) database (OECD, 2017 $[11]$ ).

StatLink הills http://dx.doi.org/10.1787/888933887614 


\section{Estimated consequences of public finance reforms}

The core analysis underpinning this report looks at the empirical evidence of long-term effects of the structure and size of government in OECD countries on output and inequality. The main tenet is that government spending and taxation, which make up from a third to above half of OECD economies' output, shape output per capita and the distribution of incomes. They mechanically influence incomes by taxing and transferring resources and indirectly by shaping economies through the targeting and quality of spending programmes and the level and design of taxes. The OECD project on the Quality of Public Finance has designed and implemented a methodological framework to quantify these effects through empirical analysis of the available statistics and simulations (see Box 1).

Public finance reforms, defined as lasting changes in the size and effectiveness of government as well as the spending structure or tax mix, can have sizeable effects on economic prosperity and the distribution of its dividends. Changes do not have uniform effects across the distribution: some reform avenues offer potential for simultaneously improving average output and making the income distribution more equal. Other ones can bring progress only along one dimension (output or equality), while some involve tradeoffs between average output gains and distributional effects.

\section{Box 1. Framework for the analysis}

The analytical framework captures impacts on output per capita and disposable income after direct and indirect effects have played out. Direct effects relate to the mechanical impacts whereby taxes and spending programmes change the distribution of income even if the economic decisions of households and firms are not affected. Indirect effects on output and inequality arise because taxes and spending programmes also influence economic decisions.

Econometric investigations estimate effects of public finance structure on real output per capita and the distribution of real household disposable income. Simulations then combine the estimates for output per capita and income distribution to quantify disposable income impacts for each income group. This step relies on the finding by the recent OECD project on the distribution of growth dividends that changes in output per capita in the long term translate into same-sized changes in average household disposable income (Hermansen, Ruiz and Causa, 2016 $\left.{ }_{[12]}\right)$. Annex A describes the analytical framework for estimations and simulations in greater detail.

The framework analyses impacts on output per capita and on real disposable income, that is to say the amount of resources available to households after paying taxes and receiving cash transfers. The empirical investigations probe the output and inequality effects of public finance policy that relate to:

- the size of government, measured by the ratio of spending to GDP, and its effectiveness, gauged with survey-based indicators;

- the spending mix, i.e. expenditure shifts from one category to another for an unchanged overall size of government, and

- the revenue mix, i.e. changes in the tax mix for an unchanged overall government size. ${ }^{1}$ 
The empirical investigations use indicators of government size, effectiveness and structure covering OECD countries since the 1980s wherever possible. The empirical framework abstracts from cyclical effects. It does so by checking whether the results are sensitive to the cycle and, where this is be case, uses cyclically-adjusted variables. In particular, potential output per capita is used, thereby eliminating cyclical effects (OECD, $\left.2016_{[13]}\right)$

On the spending side, internationally comparable indicators that span several decades have been prepared (Bloch et al., 2016 $[2]$ ). A major strength of this database is that it breaks down overall government expenditure in eleven functional categories (e.g. education, health) that are defined consistently across countries and cover a sufficiently long time period (i.e. starting in the late 1980s or early 1990 s for most countries) to permit identifying effects that take hold slowly. The measure of government effectiveness comes from the World Governance Indicators published by the World Bank, which summarise information gleaned from surveys (Kaufmann, Kraay and Mastruzzi, 2011 $[14])$.

On the revenue side, the investigations evaluate the impact of tax policy by looking at tax rates, rather than revenue shares, wherever possible. More precisely, the analyses rely on effective tax rates, when these are available, since they better capture what influences economic decisions than statutory rates. Annex A provides additional information on the tax indicators and their sources.

The empirical investigations cover many yet not all public finance drivers on economic outcomes. In particular, effectiveness within each tax and spending category is only partly covered through its contribution to overall government effectiveness as measured by the World Governance Indicators.

1. The baseline empirical analysis gauges the effect of tax changes for an unchanged government size measured by spending, but all the results have been checked to verify that they hold when controlling for overall government revenue, so that they can also be interpreted as revenue-neutral changes (Akgun, Cournède and Fournier, 2017 $[6]$ ).

This section is organised around this taxonomy, starting with areas with win-win potential, continuing with options that promise better average output for broadly unchanged inequality. It then discusses possibilities to enhance disposable income equality without affecting average output before moving to trade-offs and closing with areas where the framework did not detect significant effects. Within each area, the items are ordered from most to least economically significant. This ranking is based on the magnitude of the estimated consequences of past typical adjustments (measured by the standard deviation of within-country changes) in an average country (when the effects depend on country characteristics, which is the case for government size and effectiveness).

\subsection{Areas with reform potential for higher and more equitably distributed incomes}

\subsubsection{Lower labour tax wedges on low income earners}

The analysis points to strong potential for improvements in the overall level and distribution of incomes from reducing the labour tax wedge on low-income 
earners (Figure 5). These favourable outcomes for equality and efficiency stem from direct and indirect effects. The direct effect simply reflects that a revenue-neutral reform reducing the tax wedge for low-income earners and improves their relative income. A strong indirect effect arises in addition, because taxes on low labour earnings are more distortive than most other revenue sources, so that a revenue-neutral reform reducing them is likely to boost labour supply and output per capita. ${ }^{1}$

Greater simplicity in the tax and benefit system is another area for reform that can benefit everybody and in particular the poor (Brys et al., 2016 $6_{[7]}$ ). Tax complexity involves costs: many people choose less financially favourable, but simpler options. This cost of complexity is regressive: it affects mostly less-well educated, low income and low-skilled people (Aghion et al., 2017 $[15]$; Kaplow, 1996 $[16])$.

\section{Figure 5. Moving the tax burden away from low-wage earners improves incomes for all}

Simulated long-term percentage effect on disposable income by decile of a one percentage-point cut in the labour tax wedge applicable at $67 \%$ of average income while keeping overall revenue constant

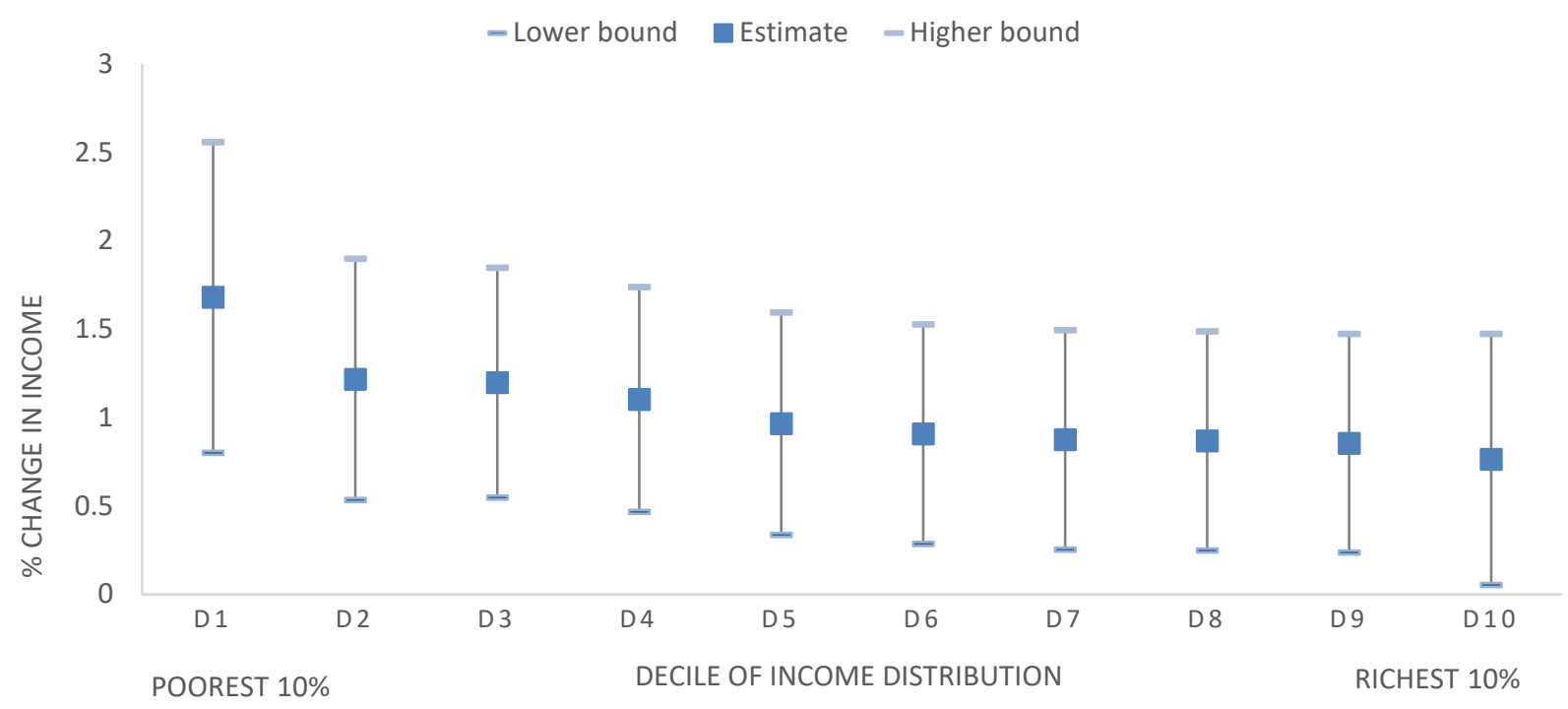

Note: The blue squares show the point estimates surrounded by $90 \%$ confidence intervals. The simulations keep the labour tax wedge constant at other income levels but raise all other taxes uniformly to make up for the revenue shortfall. A one percentage point reduction in the labour tax wedge at $67 \%$ of average earnings is within the range of typically observed long-term changes, as the average within-country standard deviation of this tax wedge is 1.7 percentage points. The estimates come from panel regressions covering 34 OECD countries over 1981-2014 or fewer observations depending on data availability (see Annex B).

Source: Authors' calculations based on (Akgun, Cournède and Fournier, 2017[6]).

StatLink 제으 http://dx.doi.org/10.1787/888933887633

1. The strong response of disposable income to a reduction of the labour tax wedge on low wages is in line with earlier findings that low-income workers are particularly responsive to lower taxes and other work incentives (OECD, 2011 ${ }_{[87]}$; Matikka, 2017 $\left.{ }_{[107]}\right)$. Tax and benefit systems often create high marginal effective tax rates for low-income workers. Consequently, reforms that have introduced in-work benefits or tax credits that improve low-income workers' net gains after taxes and benefits from additional work have had success in boosting economic activity (Brewer et al., 2006 $[88]$; Blundell et al., 2009 ${ }_{[89]}$; Aaberge and Flood, $\left.2013_{[90]}\right)$. 


\subsubsection{Higher inheritance taxes}

Tax reforms that shift the revenue mix towards greater reliance on inheritance taxes have a significant positive effect on output per capita (Figure 6). This finding suggests that, even though estate taxation reduces the incentive to save, its economic cost is smaller than that of the other taxes that can be cut when raising more revenue from inheritance tax.

Furthermore, households in the lower part of the income distribution gain more in terms of disposable income from stronger use of inheritance taxes. A revenue-neutral shift towards inheritance taxes indeed raises the tax burden on the better-off and allows cutting more distortionary taxes, which in turn boosts growth. Households in the top decile represent the only group that does not experience a statistically significant increase in their disposable income when the revenue mix shifts towards inheritance taxes (Figure 6). Two potential channels behind this effect are that higher inheritance taxes may imply lower stocks of wealth, resulting in smaller flows of capital income, by creating incentives to shift wealth away from the tax base and, in the very long term, by weakening the intergenerational transmission of wealth. Through their effects on transmission, inheritance taxes are likely to produce even more progressive effects on the distribution of wealth than income.

Figure 6. Shifting the tax mix towards inheritance taxes enhances average income and makes its distribution more equal

Simulated percentage change in income by decile of a revenue-neutral reform involving a permanent 0.1 percentage point increase in the ratio of inheritance tax revenue to GDP

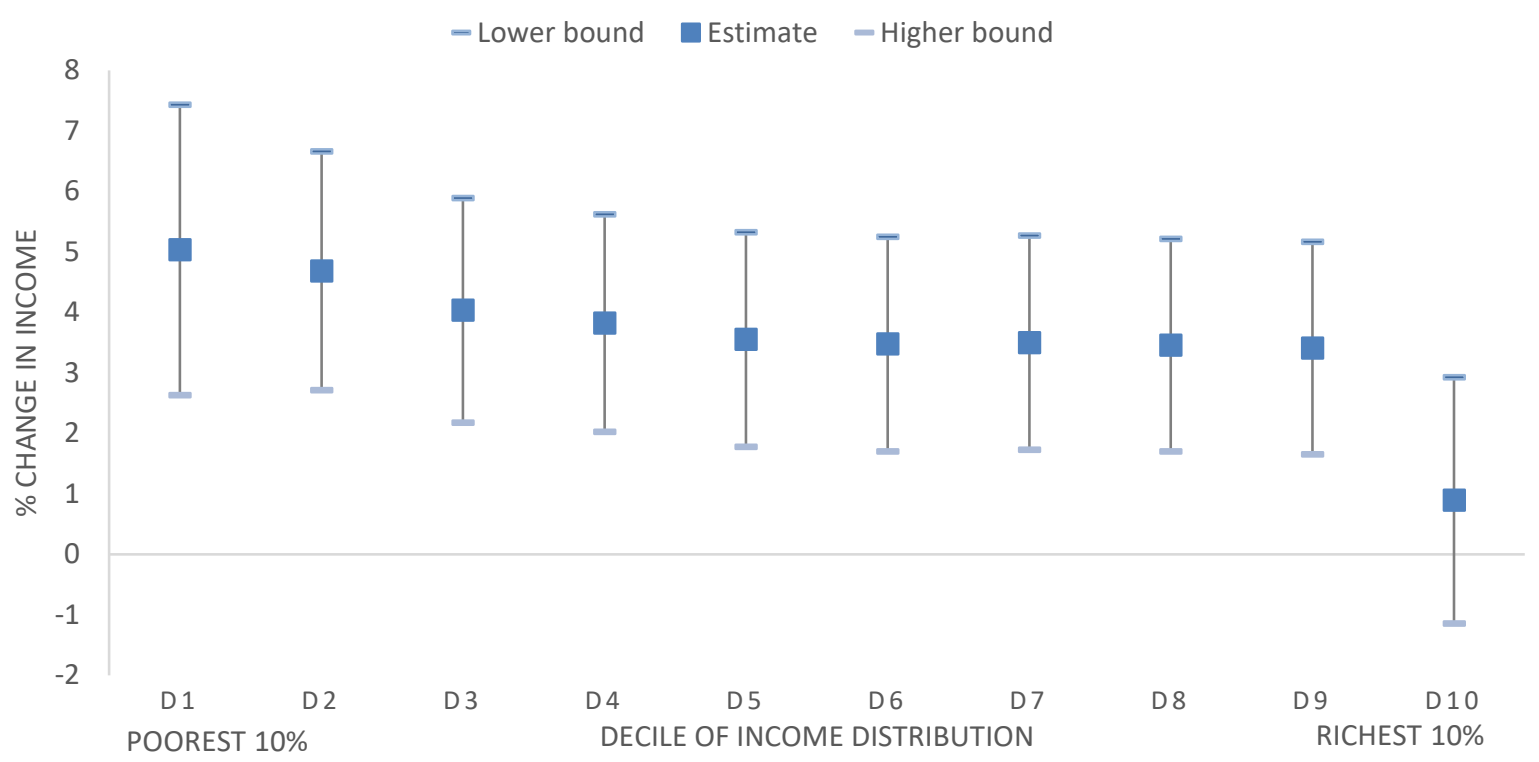

Note: The blue squares show the point estimates surrounded by $90 \%$ confidence intervals. A 0.1 percentage point increase in the ratio of inheritance taxes to GDP is in the upper range of the long-term changes that have been observed in OECD countries, as the average within-country standard deviation of this ratio is 0.06 percentage points. Estimates come from panel regressions covering 34 OECD countries over 1981-2014 or fewer observations depending on data availability (see Annex B).

Source: Authors' calculations based on (Akgun, Cournède and Fournier, 2017 $[6]$ ).

StatLink 제으 http://dx.doi.org/10.1787/888933887652 


\subsubsection{Greater government effectiveness}

Greater government effectiveness is in general linked with reduced inequality (Fournier and Johansson, 2016 $\left.{ }_{[3]}\right)$. Effective governments are associated with better targeting of disadvantaged groups and more cost-efficient delivery of transfer programmes. In countries with large governments, higher effectiveness is also associated with higher output per capita, as greater government effectiveness appears to offset some of the distortions that large tax and transfer systems generate (Fournier and Johansson, 2016 ${ }_{[3]}$ ). The World Governance Indicator of government effectiveness used for the analysis measures perceptions of the quality of public services, the civil service and the policy process (Kaufmann, Kraay and Mastruzzi, 2011 $[14]$ ). Consequently, government effectiveness is not a directly actionable policy variable, but a number of government interventions (such as boosting growth, improving education and enhancing gender equality) have been shown to result in greater government effectiveness (Garcia-Sanchez, Cuadrado-Ballesteros and Frias-Aceituno, 2013 $\left.{ }_{[17]}\right)$.

\subsection{Areas with reform potential for higher average output with no significant adverse impacts on disposable income inequality}

A number of reforms to the spending and tax mix can boost average output per person with no significant estimated effects on the distribution of income. Effects on average output per person in the long term translate into same-sized effects on average household disposable income as shown by earlier OECD analysis (Hermansen, Ruiz and Causa, $\left.2016_{[12]}\right)$. These structural public finance reforms involve shifts among different categories of taxes or spending items while keeping overall government size constant. Scaling reforms by the size of typically observed changes shows that reforms of the spending structure have, on average, a greater impact on GDP per capita than tax shifts (Figure 7). This sub-section discusses these instruments from largest to smallest estimated effects on output per capita.

\subsubsection{Greater public investment}

The area of public spending that offers the greatest estimated potential for lifting longterm output is public investment. More detailed OECD investigations confirm this result (Fournier, 2016 $\left.{ }_{[4]}\right)$. These gains are particularly strong when public investment focuses on health (that is, hospitals and their equipment) and research and development. The growth gains from increasing public investment, however, appear to decline at high levels of the public capital stock and generally become negative at the margin when this stock is larger than $90 \%$ of GDP (Fournier, 2016 $\left.{ }_{[4]}\right) .^{2}$ Taking this estimate at face value, all OECD countries bar Japan appear to still have substantial room for additional public investment.

2. This finding reflects what has been observed on average across OECD countries over the past three decades: specific projects will be valuable or not depending on their cost-benefit ratio however large the public capital stock may be in the country where they are considered. The influence of the existing public capital stock will be felt when evaluating costs and benefits, which will depend on the value that a new project can bring in addition to what existing public capital already provides. 


\section{Figure 7. Many public finance shifts can boost average output with no adverse consequences for income inequality}

Permanent percentage effect on output per capita of a typically observed long-term change in a public finance instrument while keeping overall government size constant ${ }^{1}$

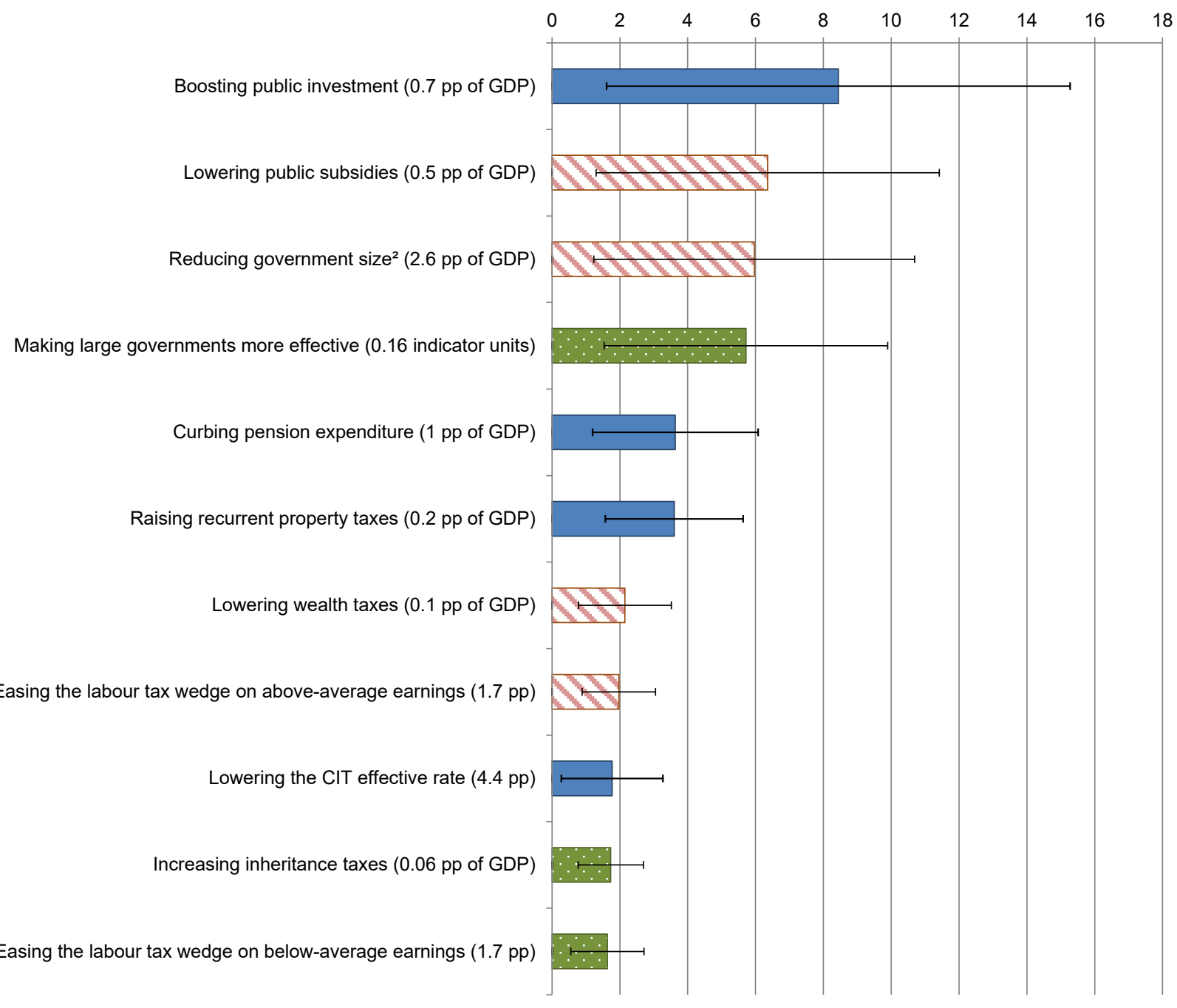

$\square$ Inequality-widening $\square$ Inequality-narrowing $\square$ No statistically significant effect on inequality ${ }^{3}$

Notes: 1. The bars show the point estimates while bracketed solid lines depict the $10 \%$ confidence intervals. Estimates come from panel regressions covering 34 OECD countries over 1981-2014 or fewer observations depending on data availability (see Annex B). A typically observed long-term change in a public finance instrument is defined as the average across countries of the standard deviation in the tax or spending instrument over time. The standard deviation is calculated only within-country changes, implying that it reflects changes that have occurred within countries rather than long-standing differences across countries. They are equal to percentage point changes in the ratios to GDP, denoted as "pp of GDP", for instruments measured as ratios to GDP. They are simple percentage point changes for tax rates or wedges. For education quality, the standard deviation is a $1.3 \%$ increase in the average PISA score. For government effectiveness, the standard deviation is calculated in units of the effectiveness measure in the World Governance Indicators.

2. By exception, government size is not kept constant for this change.

3. Inequality relates to disposable income inequality within the working-age population.

Source: (Akgun, Cournède and Fournier, 2017 $7_{[6]}$; Fournier and Johansson, 2016 $6_{[3]}$ ) and OECD calculations.

StatLink त्ञाI $\mathrm{http}: / / \mathrm{dx}$.doi.org/10.1787/888933887671 


\subsubsection{Reduced public pension expenditure}

A higher share of pension spending in government expenditure (holding demographic variables constant) is associated with lower long-term output and no significant link with distributional outcomes among the working-age population (Figure 7).

- On the output side, the result is consistent with the literature suggesting that more public spending on pensions typically reduces labour supply (Feldstein, 1996 ${ }_{[18]}$ ). Greater government spending on pensions often implies that public pension arrangements allow early retirement or provide higher replacement rates. Early retirement directly reduces the productive potential of an economy by shrinking the labour supply; higher replacement rates create incentives to the same effect. The strength of the disincentive to pursue work will depend on the design of pension systems, especially the tightness of the link between contributions and pensions. ${ }^{3}$

- The absence of a significant inequality effect should be interpreted with caution, as it relies on statistics measuring inequality within the working-age population. Public pension schemes usually have a sizeable redistributive component towards the most vulnerable pensioners (Lefèbvre, 2007 ${ }_{[19]}$; OECD, 2015 $[20]$; OECD, 2017 [21]). Reforms to contain public pension spending might therefore potentially entail potential adverse effects on old-age poverty unless they are designed to include an adequate safety net (OECD, 2015 [20]; OECD, 2017 [21]).

\subsubsection{Greater use of recurrent property taxes}

Shifting the revenue mix towards greater reliance on recurrent property taxes is also growth-friendly (Figure 7). The empirical investigations found a positive effect of higher recurrent property taxes (with the extra revenue used to reduce other taxes) on average output without significant adverse effects on income inequality on average across OECD countries (Akgun, Cournède and Fournier, 2017 ${ }_{[6]}$ ). The growth-friendliness of property taxes, by comparison with other revenue sources, corroborates earlier empirical findings (Arnold et al., 2011 [22]; Norregaard et al., 2013 [23]; Blöchliger et al., 2015 [24]; Brandt, 2014 [25]; Høj, Jørgensen and Schou, 2018 ${ }_{[26]}$ ) and is also in line with tax theory, which recommends taxing immobile factors such as land (Blöchliger and Kim, 2016 [27]). However, recurrent property taxes often also tax the value of structures: there is therefore a case for basing recurrent property tax more on the land value and less on the property price including structures (Mills, 1998 ${ }_{[28]}$; Oates and Schwab, 1997 ${ }_{[29]}$ ). In practice, hiking property taxes typically raises particularly strong political-economy obstacles, for a good part because the link between local taxes and local public services is in most countries quite loose (Slack and Bird, 2014 $[30]$ ).

3. Private pension arrangements may in principle produce similar effects, but the empirical finding of a negative effect of public pension spending suggests that private schemes do not produce comparably strong negative effects. This difference reflects that the funding component of private pensions can boost investment, though the size of the effect is uncertain (Kohl and O'Brien, $\left.1998_{[92]}\right)$. It also comes from the frequently tighter link that private pension arrangements create between benefits and contributions, which reduces the negative effects of pension contributions on labour supply (Disney, 2004[95]). Earlier OECD work has underlined that retirement decisions are highly sensitive to the retirement incentives that public pension systems generate (Duval, 2004 ${ }_{[91]}$ ). 


\subsubsection{Higher quality education}

High quality education is a driver of long-term prosperity. The estimates identify a positive effect of the quality of education, measured by a country's average PISA test scores, on long-term output per capita (Figure 7). Additional years of schooling are also found to be associated with a higher long-term level of output per capita (Fournier and Johansson, 2016 $\left.6_{[3]}\right)$. These effects differ from the other ones in this study, as they relate to the quality of spending, while the amount of government spending on education turns out to have no statistically significant link with long-term output per capita (Fournier and Johansson, 2016 $\left.{ }_{[3]}\right)$. These results are consistent with earlier findings that, in advanced economies, education outcomes have only a weak relationship with spending but a tighter one with the quality of resources and efficiency of their use (Hanushek and Woessmann,

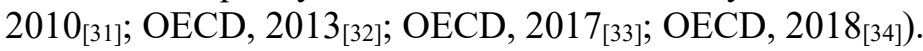

There is also no significant link between overall education spending and disposable income inequality, but more detailed investigations indicate that stronger secondary education attainment reduces disposable income inequality (Fournier and Johansson, $\left.2016_{[3]}\right)$. This result corroborates evidence that a higher share of workers with postsecondary non-tertiary education lowers wage inequality in most OECD countries (Fournier and Koske, 2012[35]).

\subsubsection{Lower effective corporate income tax rates}

Reforms of the tax structure that lower effective rates of corporate income taxation (CIT) have the potential to raise average output with no statistically significant effect on inequality (Figure 7). The positive effect of lower effective CIT rates on output is in line with a vast literature, including past OECD work, that documents the negative effects of

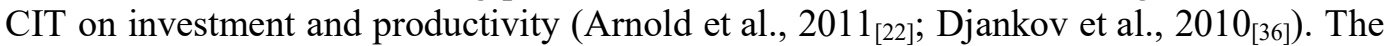
underlying empirical estimates also find an effect of effective CIT rate differentials with neighbouring countries, corroborating earlier OECD research and a body of economic literature identifying a link via foreign direct investment (Hajkova et al., 2007 [37]; Feld and Heckemeyer, 2011 $\left.{ }_{[38]}\right)$.

No clear effect of changes in effective rates of corporate taxation on disposable income distribution was detected (Akgun, Cournède and Fournier, 2017 $[6]$ ). This observation runs against widespread perceptions that taxing corporations is equivalent to taxing the rich but is in line with findings that, in open economies, capital mobility results in most of the burden of CIT falling on labour (Cronin et al., 2013 [39]; Randolph, 2006 [40]; Fullerton and Metcalf, 2002 ${ }_{[41]}$ ) and land (Suárez Serrato and Zidar, 2016[42] $)$. A greater incidence of CIT on capital, and a therefore stronger effect of CIT changes on high-income households, might be expected in larger, comparatively more closed OECD economies (Cronin et al., 2013 ${ }_{[39]}$; Piketty and Saez, 2007 ${ }_{[43]}$ ). Besides, recent research suggests that the share of the CIT burden that falls on labour is concentrated on low-skilled workers, women and young workers while leaving high-skilled employees unaffected (Fuest, Peichl and Siegloch, 2018 [44] $)$.

CIT might nevertheless have distributional effects on wealth inequality. Indeed, the statistics underpinning this analysis, while they cover capital income, do not include capital gains, which are not part of the definition of disposable income. Given that closely held businesses have played an important role in the rise of income inequality (Smith et al., 2017 $7_{[45]}$ ), exploring the effects of CIT reforms on changes in the distribution of wealth would be an interesting avenue for future research. 


\subsection{Areas with distributional income implications but no significant average output effect}

\subsubsection{Higher child and family benefits}

Spending more on child and family benefits while scaling back other expenditure areas to keep government size constant generally benefits low-income households but with considerable differences across countries (Fournier and Johansson, 2016 $6_{[3]}$ ). Indeed, the estimated effect of shifting government expenditure towards spending more on child and family benefits is economically large but surrounded by wide confidence intervals, which reflect strong variation across OECD countries in spending levels and policy design. In addition to the investigations undertaken for the Quality of Public Finance project, earlier and recent OECD and other studies have documented the strong redistributive power of child and family benefits (Joumard, Pisu and Bloch, 2012[46]; Causa and Akgun, 2018 ${ }_{[9]}$; European Commission, 2017 $[47])$.

\subsubsection{Greater use of environmentally related taxes}

Revenue shifts towards greater reliance on environmental taxes, which enhance wellbeing by reducing pollution, require a well-designed policy strategy to fend off the risk of widening disposable income inequality. Because increases in environmental taxes can be regressive for income distribution (Akgun, Cournède and Fournier, 2017 ${ }_{[6]}$ ), there is a case for tax reforms that increase environmental taxes while reducing low and middleincome tax wedges (Oueslati et al., 2016 [48]; OECD, 2006 [49]). A simulation below shows that such a combination can be effective in boosting average output and more than compensate adverse effects on disposable income inequality (Section 4).

Environmental taxes may have distributional consequences for consumption that can differ from the ones for disposable income with the possibility that they may be more regressive. The reason is that the composition of consumption, in particular its share of transport and heating fuels, varies with the income level (OECD/KIPF, 2014 [50]; Flues and Thomas, $\left.2015_{[51]}\right)$.

However, the environmental benefits of green taxes can be expected to be larger for the poor. Underprivileged households should benefit more from better environmental quality, as they tend to be more exposed to pollution than higher income households, especially in urban areas (Finkelstein et al., 2003 $3_{[52]}$; Pinault, van Donkelaar and Martin, 2017[53]; Serret and Johnstone, 2006 $\left.6_{[54]}\right)$.

\subsection{Areas involving output-inequality trade-offs}

A number of public finance reforms present potential to improve output per capita but at the cost of greater inequality in the distribution of household disposable income. This sub-section reviews them starting from the ones where, quantitatively, typically observed changes correspond to the greatest potential for long-term output gains. The empirical framework allows putting together output and distributional effects so as to ascertain which dominate for the poor and determine if, in absolute terms, they stand to gain or lose from reforms despite the output-inequality trade-off.

\subsubsection{Reducing government size}

The size of government is an important area where trade-offs can arise, except where government effectiveness is high. A two-way relationship generally holds: more 
redistribution requires larger public expenditure, and larger governments typically redistribute more (Fournier and Johansson, 2016 $6_{[3]}$; Causa and Hermansen, 2017 ${ }_{[8]}$ ). On the other hand, larger governments are typically associated with lower long-term levels of output per capita, because of the distortions associated with high tax levels and disincentives to labour supply that spending programmes can entail, except when governments are very effective (Fournier and Johansson, 2016 $[3]$; Afonso and Jalles, $\left.2011_{[55]}\right)$.

Figure 8. Reducing government size typically involves a trade-off between growth and equality but still increases incomes for most

Percentage change in household disposable income by decile when reforms permanently reduce the government expenditure to GDP ratio by one percentage point in countries with median government effectiveness

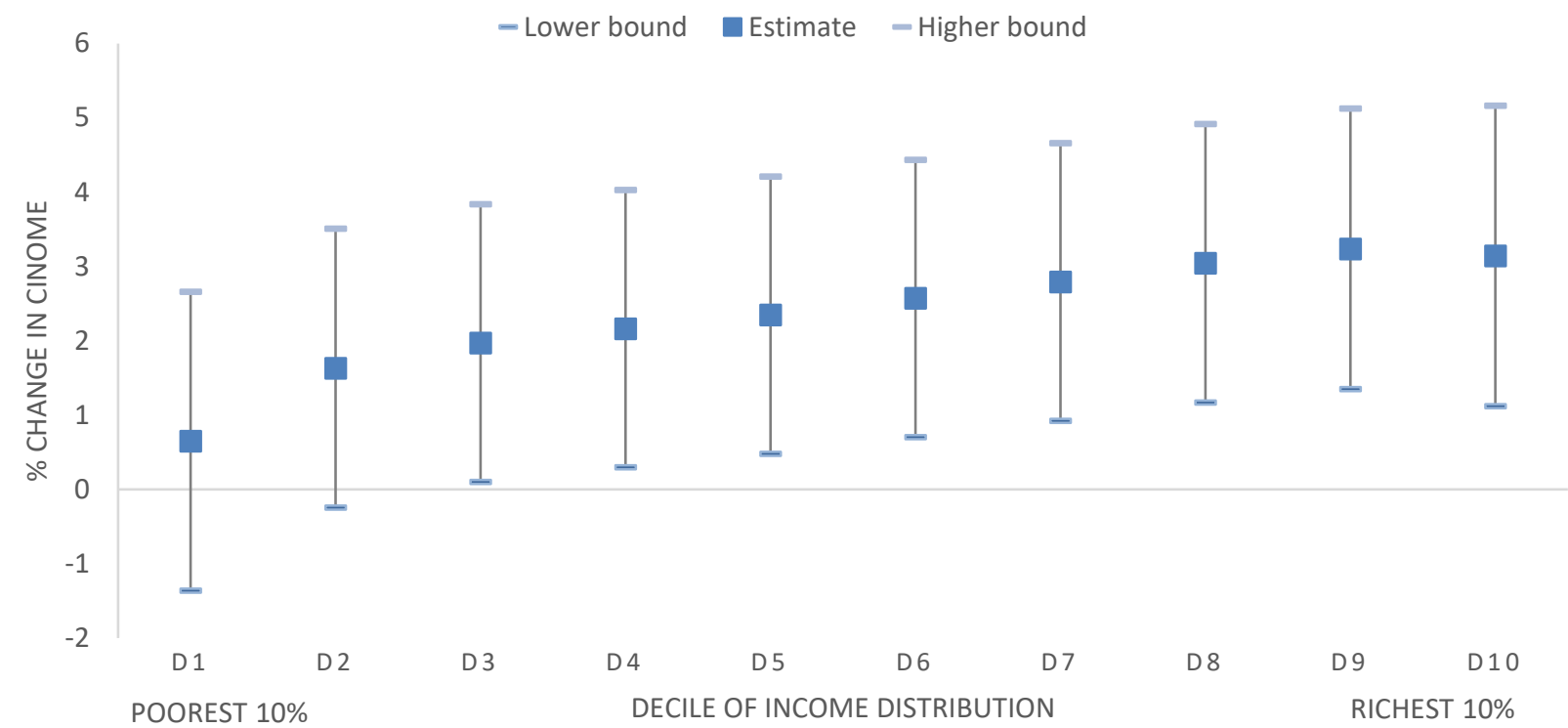

Note: The blue squares show the point estimates surrounded by $90 \%$ confidence intervals. Estimates come from panel regressions covering 34 OECD countries over 1981-2014 or fewer observations depending on data availability (Annex B). Over the long term, a one percentage point change in the ratio of government expenditure to GDP is quite common, since the within-country standard deviation is $2.6 \mathrm{pp}$ of GDP. The effects vary depending on the level of government effectiveness: this chart depicts the estimated effects at median government effectiveness in 2012 as measured in the World Governance Indicators.

Source: Authors' calculations based on (Fournier and Johansson, 2016 $6_{[3]}$ ).

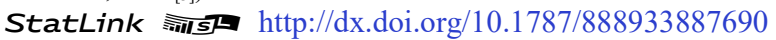

The positive output effects, however, more than offset the adverse inequality effects of reducing public spending in a country with median government effectiveness: in absolute terms, lower public spending is linked with higher income levels across nearly all income groups (Figure 8). This result becomes stronger if looking at OECD countries where perceived government effectiveness is below average: in such cases, cuts in public spending, while increasing relative disposable income gaps, increase output per capita and therefore household disposable incomes for all groups in absolute terms (Figure 9). On the other hand, at high levels of government effectiveness as observed in the three most effective OECD countries (Finland, Denmark and Sweden), there is no outputinequality trade-off, as a larger government is compatible with higher output levels while allowing more redistribution (Fournier and Johansson, 2016 $\left.6_{[3]}\right)$. 
Figure 9. Reducing government size increases incomes for all in countries with low perceived government effectiveness

Percentage change in household disposable income by decile when reforms permanently reduce the government expenditure to GDP ratio by one percentage point in countries with government effectiveness equal to the cut-off point for the bottom quarter of OECD countries

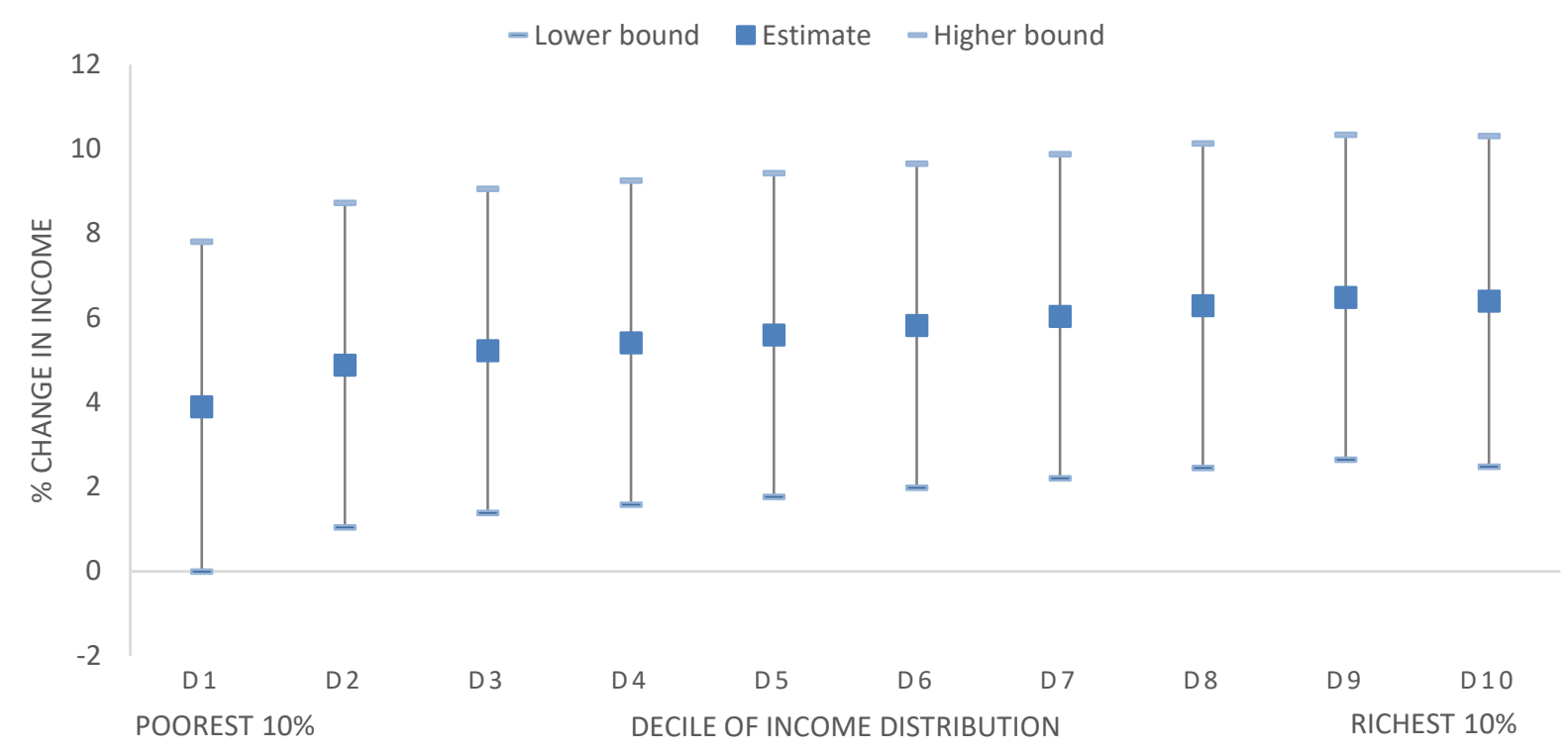

Note: The blue squares show the point estimates surrounded by $90 \%$ confidence intervals. Estimates come from panel regressions covering 34 OECD countries over 1981-2014 or fewer observations depending on data availability (Annex B). The effects vary depending on the level of government effectiveness: this chart depicts the estimated effects at government effectiveness in 2012 equal to the value that separates the 8 lowest OECD performers in the World Governance Indicators database from the 23 other OECD countries with available data.

Source: Authors' calculations based on (Fournier and Johansson, 2016 $6_{[3]}$ ).

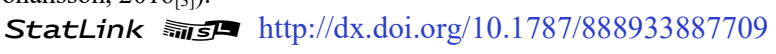

\subsubsection{Lowering public subsidies}

Lowering public subsidies in a revenue-neutral manner improves economic efficiency, boosting average output, but widens income dispersion (Fournier and Johansson, 2016 $[3]$ ). The output effect dominates, so that no income group loses in absolute terms (Figure 10). The analysis relates to production subsidies (e.g. production support in agriculture and coal extraction). The positive effect on average output comes from the inefficiencies and competitive distortions that public subsidies generate when they do not effectively correct market inefficiencies (OECD, 2004 $\left.4_{[56]}\right)$. 
Figure 10. Reducing public subsidies improves average output but only boosts incomes at the top significantly

Simulated percentage change in income by decile of a reform involving a 0.1 percentage-point of GDP decrease in government subsidies while keeping overall government size constant

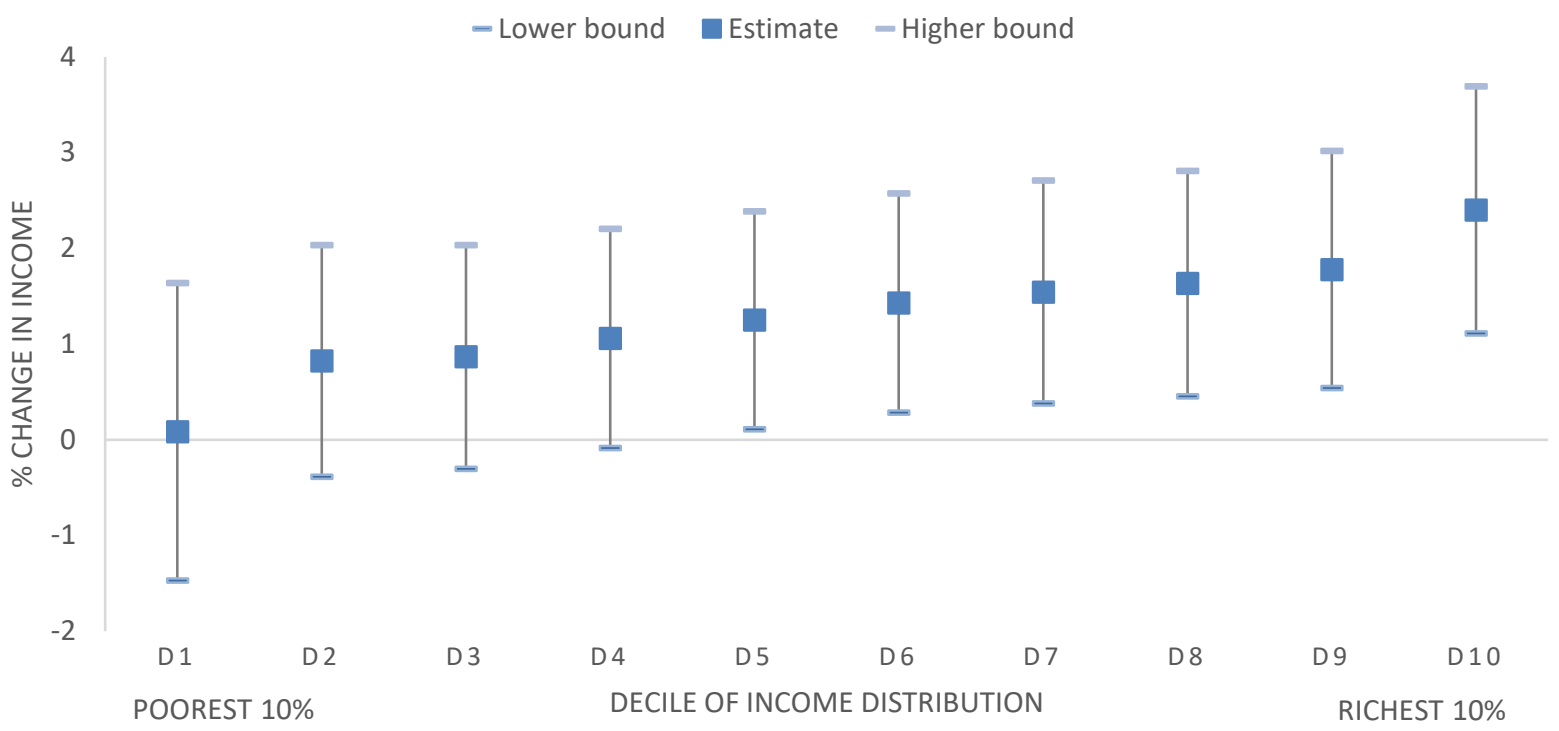

Note: The blue squares show the point estimates surrounded by $90 \%$ confidence intervals. A 0.1 percentage point of GDP reduction in public subsidies is well within the range of typically observed long-term changes within countries (which have a standard deviation of $0.5 \%$ of GDP). Estimates come from panel regressions covering 34 OECD countries over 19812014 or fewer observations depending on data availability (Annex B).

Source: Authors' calculations based on (Fournier and Johansson, 2016 $6_{[3]}$ ).

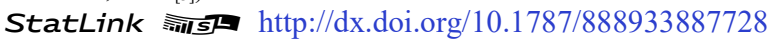

\subsubsection{Lowering wealth taxes}

The empirical inquiries find that a revenue-neutral shift towards greater reliance on net wealth taxes is associated with sharply reduced long-term output and greater disposable income equality. The strong negative growth effect of wealth taxes on output, by comparison with other taxes, is in line with theory and prior evidence that they reduce savings and therefore output (Mankiw, Romer and Weil, 1992 [57]; Tanzi, 1995 $5_{[58]}$; Hansson, 2010[59] $)$ despite a debate about the possibility that widespread tax avoidance might lower their adverse output effect (Diamond and Saez, 2011 [60]; Seim, 2017[61]). In particular, the finding of a markedly more adverse effect of wealth taxes compared with other revenue sources suggests that wealth taxes are likely to be poor substitutes for welldesigned taxes on capital income and gains. Wealth taxes nonetheless reduce wealth inequality and also disposable income inequality because of the concentration of wealth and its correlation with income.

As a consequence, lowering wealth taxes can raise average output at the cost of greater income inequality. The empirical framework of this study allows combining the two effects to gauge the absolute effects for each income group. Because the growth effect is very strong, the net outcome is that lowering wealth taxes significantly increases disposable income for almost all income groups (Figure 11). 
Figure 11. Reducing taxes on net wealth predominantly benefits the rich but raises nearly everybody's income

Simulated percentage change in income by decile of a revenue-neutral reform involving a permanent 0.1 percentage point decrease in the ratio of net wealth tax revenue to GDP

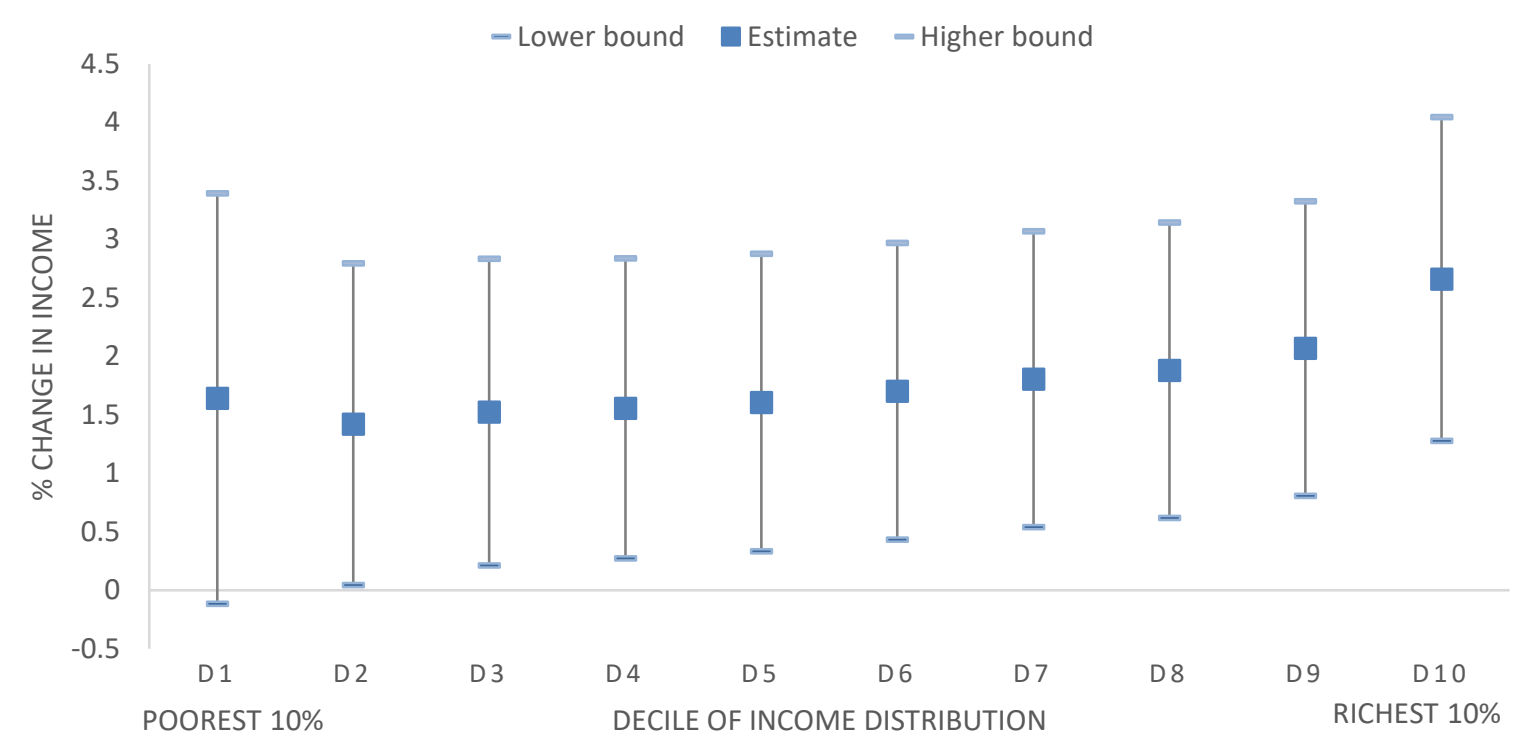

Note: The blue squares show the point estimates surrounded by $90 \%$ confidence intervals. The results are shown for a 0.1 percentage point change in the ratio of net wealth taxes to GDP to keep the change in scale with the size of the tax $(0.4 \%$ of GDP on average across the countries with a net wealth tax in 2015). Estimates come from panel regressions covering 34 OECD countries over 1981-2014 or fewer observations depending on data availability (Annex B). Source: Authors' calculations based on (Akgun, Cournède and Fournier, 2017 ${ }_{[6]}$ ).

StatLink 제핀 http://dx.doi.org/10.1787/888933887747

\subsubsection{Lowering the labour tax wedge on above-average income earners}

Lowering the labour tax wedge on above-average income earners, as part of a revenueneutral reform, is found to generate substantial average output benefits in addition to the obvious gains for the direct beneficiaries (Figure 12). This result is in line with earlier findings that high tax rates on above-average income earners, everything else being equal, harm long-term economic growth (Arnold, 2008 ${ }_{[62]}$ ). Besides, a lower labour tax wedge on above-average income earners shifts the relative income position of others down. Nevertheless, the output effect is sufficiently large that, despite this output-inequality trade-off, nearly all income groups benefit, and none loses. This empirical result is in line with recent research using general-equilibrium modelling (Lizarazo Ruiz, Peralta-Alva and Puy, 2017 $[63]$. 
Figure 12. Cutting the labour tax wedge on above-average income earners improves incomes for all

Simulated long-term percentage effect on disposable income by decile of a revenue-neutral one percentage-point cut in the labour tax wedge applicable at $167 \%$ of average income

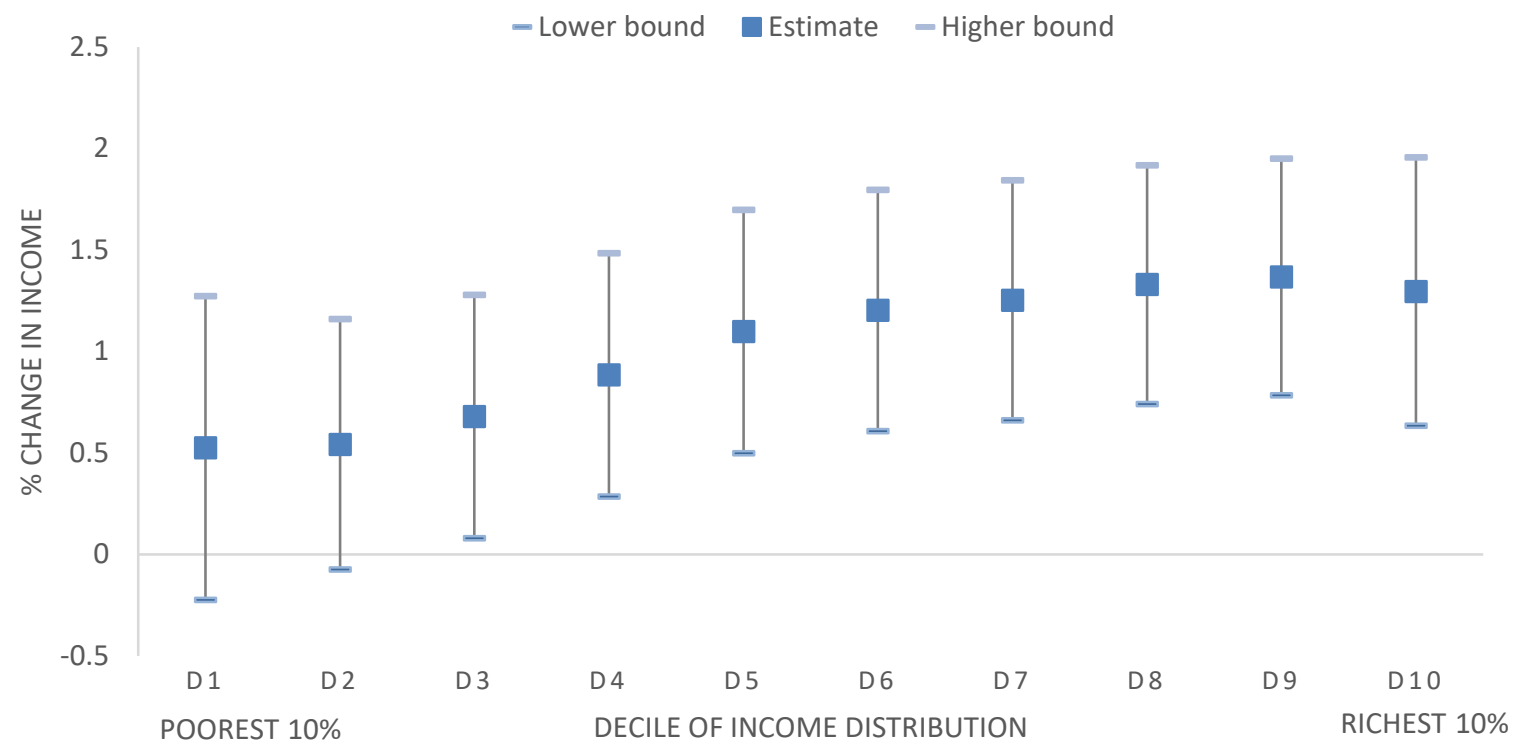

Note: The blue squares show the point estimates surrounded by $90 \%$ confidence intervals. A one percentage point reduction in the labour tax wedge on earnings at $167 \%$ of average income is well within the range of observed long-term changes, as the within-country standard deviation of this tax wedge is 1.7 percentage points. Estimates come from panel regressions covering 34 OECD countries over 1981-2014 or fewer observations depending on data availability (Annex B). Source: Authors' calculations based on (Akgun, Cournède and Fournier, 2017 ${ }_{[6]}$ ).

StatLink 제으 http://dx.doi.org/10.1787/888933887766

Areas with no robustly identified effects

The other areas of public finance reforms, for which the empirical inquiries detected no significant effects, nevertheless matter. Important examples are value-added taxation on the revenue side and general administration (including security and justice) and health expenditure on the spending side. The empirical framework (except when looking at government size) considers changes in one public finance instrument while keeping government size constant, which requires that the other instruments adjust to make room for the one under consideration.

Three areas call for specific considerations:

- Public spending on health, which is the bulk of health care spending, contributes to better health status, but better health has only a limited impact on income levels in OECD countries. Earlier OECD empirical work found that increases in health care spending account for nearly half the increase in life expectancy (Joumard et al., $\left.2008_{[64]}\right)$. Better health and higher life expectancy clearly contribute to greater wellbeing (Stiglitz, Sen and Fitoussi, 2009 [65]; White, 2007[66]; Layard, 2003 ${ }_{[67]}$ ). Better health also facilitates the acquisition and nurturing of human capital, as unhealthy children may miss school more often and poor health is an obstacle to lifelong learning. Consequently, health expenditure can support economic growth: such an effect is empirically strong in developing countries (Sala-i-Martin, Doppelhofer and Miller, 2004[68]; Aghion, Howitt and Murtin, 2010[69]; World Health Organization, $2001_{[70]}$ ) but much more difficult to pin down in advanced economies (Acemoglu and Johnson, 2007 [71]; Bhargava et al., 2001 ${ }_{[72]}$; Hartwig, 2010[73]). 
- The absence of identified positive output effects of revenue shifts involving hikes in VAT rates on average across OECD countries could reflect that, while VAT is an efficient, growth-compatible form of taxation (Arnold et al., 2011 $1_{[22]}$; Brys et al., $\left.2016_{[7]}\right)$, many OECD countries have exploited much of its potential. OECD estimates (Akgun, Bartolini and Cournède, 2017 ${ }_{[5]}$ ) underscore that many OECD countries, especially in Europe, implement standard VAT rates that are close to the revenuemaximising point (Figure 13). These countries can still have room to raise more revenue from VAT by broadening its base, especially by eliminating reduced rates and exemptions. VAT often raises concerns of possible regressivity; however, recent OECD analysis indicates that, in most countries, it is slightly progressive when measured over expenditure (rather than income), which corresponds to a lifetime (rather than point-in-time) perspective (OECD/KIPF, 2014 $[50]$ ).

- Transaction taxes are generally seen as negative for long-term output, as they hinder factor reallocation (Diamond and Mirrlees, $1971_{[74]}$ ). The empirical framework shows a negative sign which, however, is not statistically significant.

\section{Figure 13. Many countries have little room for raising standard VAT rates}

Standard VAT rates and country-specific estimates of revenue-maximising points, above which rate hikes are unlikely to produce additional revenue, 2016, per cent

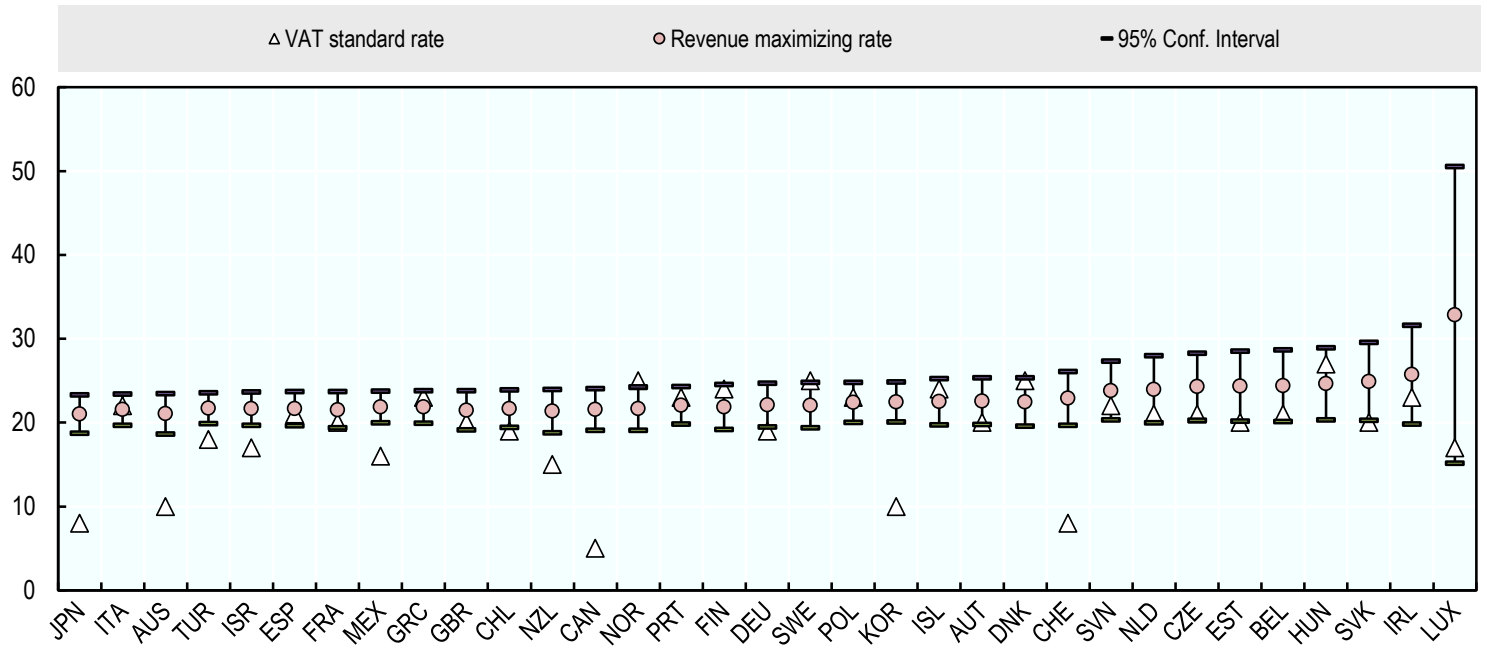

Note: Cross-country differences in import penetration rates drive the variation in country-specific revenue-maximising rates, which are calculated using Column 4 of Table 7 in (Akgun, Bartolini and Cournède, 2017 ${ }_{[5]}$ ). The bands show 95\% confidence intervals.

Source: (Akgun, Bartolini and Cournède, 2017 $\left.{ }_{[5]}\right)$.

StatLink त्ञाI http://dx.doi.org/10.1787/888933887785

\section{Scope for public finance reforms to boost inclusive growth}

OECD countries have scope for making their public finances contribute more effectively to growth and widely shared income gains. Many areas of public finance reform offer possibilities for raising incomes with a focus on the poor (Table 1). The empirical work, which covers a good part but certainly not all of the channels by which public finance instruments affect inclusive growth can be used to gauge how public finances influence long-term output per capita and income distribution. The integrated framework allows producing such estimates for average output and also for different income levels. 
Table 1. Summary of estimated effects of public finance reforms on inequality and output

Simulated net effects of public finance shifts that accompany the change under consideration by proportional adjustments of other revenue or spending items to keep government spending or revenue fixed ${ }^{1}$

\begin{tabular}{|c|c|c|c|c|}
\hline & $\begin{array}{l}\text { Equality: } \\
\text { Poor/rich }\end{array}$ & $\begin{array}{l}\text { Average } \\
\text { output }^{2}\end{array}$ & $\begin{array}{l}\text { Income }{ }^{3} \text { of the } \\
\text { poor }\end{array}$ & $\begin{array}{l}\text { Income }{ }^{3} \text { of } \\
\text { the rich }\end{array}$ \\
\hline $\begin{array}{l}\text { Greater government effectiveness (at average } \\
\text { government size) }\end{array}$ & (;) & n.s. & (ن) & n.s. \\
\hline $\begin{array}{l}\text { Greater government effectiveness (in countries with } \\
\text { large public expenditure) }\end{array}$ & (:) & (ت) & (ヒ) & (:) \\
\hline $\begin{array}{l}\text { Reduced expenditure (for governments with close to } \\
\text { or below average effectiveness) }\end{array}$ & 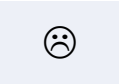 & $(-)$ & $(-)$ & (ச) \\
\hline \multicolumn{5}{|l|}{$\begin{array}{l}\text { Keeping government size constant, effects of } \\
\text { spending reforms that: }\end{array}$} \\
\hline Increase public investment & n.s. & $(\bullet)$ & & $(\bullet)$ \\
\hline Reduce public subsidies & $\because$ & $(\bullet)$ & n.s. & (ن) \\
\hline Reduce pension expenditure & n.s. & $(\bullet)$ & 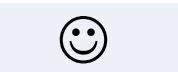 & $(\ddot{)}$ \\
\hline Enhance education quality & n.s. & $(\ddot{)}$ & 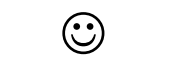 & $(\dot{)}$ \\
\hline Increase child and family benefits & (:) & n.s & (:) & n.s \\
\hline \multicolumn{5}{|l|}{$\begin{array}{l}\text { Keeping overall revenue constant, effect of tax reforms } \\
\text { that: } 4\end{array}$} \\
\hline Lower tax wedge on upper-middle incomes & $\ddot{6}$ & (;) & $(\ddot{)}$ & $(\bullet$ \\
\hline Lower tax wedge on lower-middle incomes & $(-)$ & $(\bullet)$ & $(\bullet$ & $(\dot{\theta}$ \\
\hline Reduce the effective $\mathrm{CIT}$ rate ${ }^{5}$ & n.s. & $(\bullet)$ & $(\bullet$ & $(-)$ \\
\hline Change the standard VAT rate ${ }^{5}$ & n.s. & n.s. & n.s. & n.s. \\
\hline Make greater use of environmental taxes ${ }^{6}$ & : & n.s. & 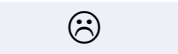 & (:) \\
\hline Raise recurrent immovable property taxes & n.s. & (:) & (ن) & $(-)$ \\
\hline Raise inheritance taxes & $(\ddot{)}$ & (:) & $(\bullet)$ & (:) \\
\hline Cut taxes on net wealth & 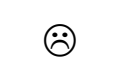 & $(\bullet)$ & $(\dot{)}$ & $(\bullet$ \\
\hline
\end{tabular}

Notes:

1. For a given instrument, the size of smileys reflects the relative size of the effect across the different outcomes. The equality effect reflects the difference between the effects on the poor and the effect on the rich within the working-age population. The poor are defined as the bottom income quintile and the rich as the top one. These estimates summarise observed experience: the impact of a specific reform in a particular country may be different, because of country or reform specificities.

2. Output results relate to long-term GDP per capita.

3. Income refers to the long-term levels of disposable income for households where the household head is of working-age, adjusted by household size.

4. The sign of the change in spending or tax (increase or decrease) is chosen so that the average output effect is positive, to facilitate comparisons.

5. CIT is corporate income tax and VAT is value added tax.

6. Other dimensions of well-being than income, such as effects on environmental quality and on the level and composition of consumption (for a given level of income), do not enter this assessment.

Source: (Fournier and Johansson, 2016 $[3]$; Akgun, Cournède and Fournier, 2017 $[6]$ ). 


\subsection{The current situation}

The estimated effects of the public finance size and structure on average output per capita vary considerably across OECD countries (Figure 14). Quantitatively, government size has a substantial influence, so that smaller governments (e.g. Japan, Korea and the United States) are associated with higher levels of output per capita than larger ones, except when these record high levels of effectiveness (e.g. Denmark, Finland and Denmark). The quality of public education is also an important driver of the overall estimated contribution of the public finances to long-term output levels (e.g. Korea).

\section{Figure 14. The estimated effects of public finance size and structure on output per capita} vary considerably across OECD countries

Index of long-term effect of government size, effectiveness and structure of spending and revenue on output per capita, deviation from OECD average

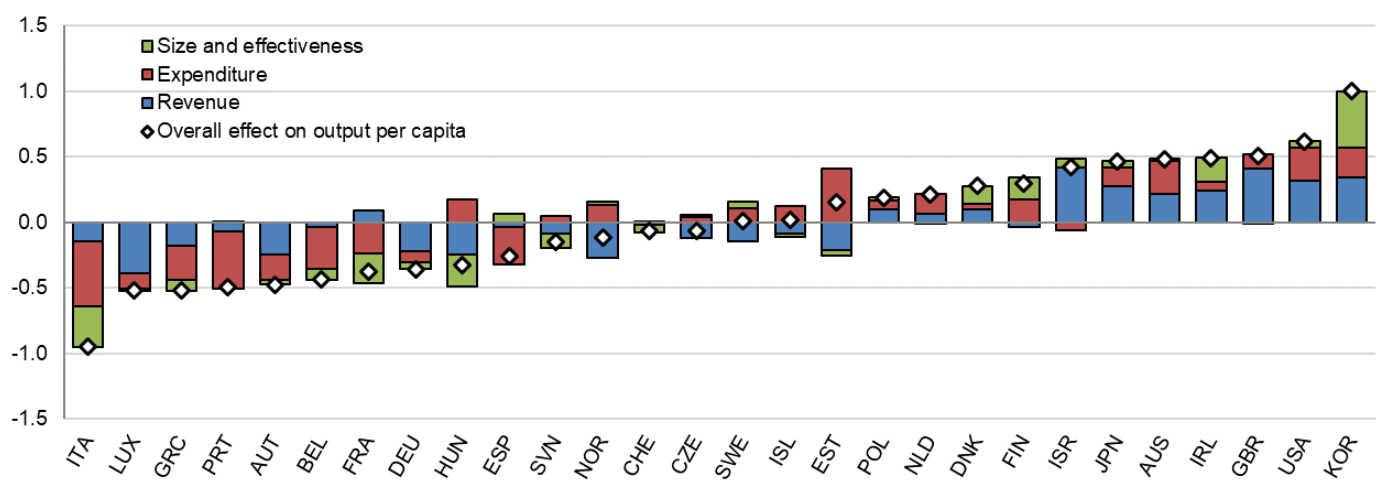

Note: The index uses output elasticities (from the two papers quoted in the source) to compare across countries how the structure of spending and revenue as well as the size and perceived effectiveness of government influence long-term output per capita. The simulated effect is scaled to be equal to 1 in the country where the simulated effect of public finance structure, size and effectiveness on output per capita is furthest above the OECD average. The estimates come from panel regressions covering 34 OECD countries over 1981-2014 or fewer observations depending on data availability (Annex B). This chart only shows countries for which all instrument-level variables are available to ensure comparability. The chart is based on the most recent data (2014-18).

Source: Authors' calculations based on (Akgun, Cournède and Fournier, 2017 $[6]$; Fournier and Johansson, $2016_{[3]}$ ).

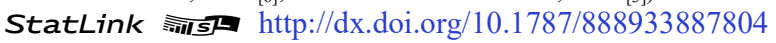

The effects of public finance settings on household income vary across the distribution (Figure 15). Countries with large social transfers exhibit substantially more favourable effects on the poor than on average output (e.g. Denmark, Finland, France and Sweden in Figures 14 and 15 Panel A).

In spite of this variation across the distribution, the absolute effect of public finance settings on the disposable income of each decile is quite closely related to their effect on output per capita. For instance, where the contribution of public finance settings to output per capita is much more positive than the OECD average, e.g. Korea, Ireland and the United States (Figure 14), their contribution to the disposable incomes of the low, middle and high-income groups are well above the OECD average as well (Figure 15). The reason is that a given change in public finance settings typically moves the level of output per capita by a quantitatively larger amount than the changes it will make within the income distribution. 
Figure 15. The effects of public finance on disposable income vary across income categories

A. Effect on disposable income of the bottom income quintile, deviation from OECD average
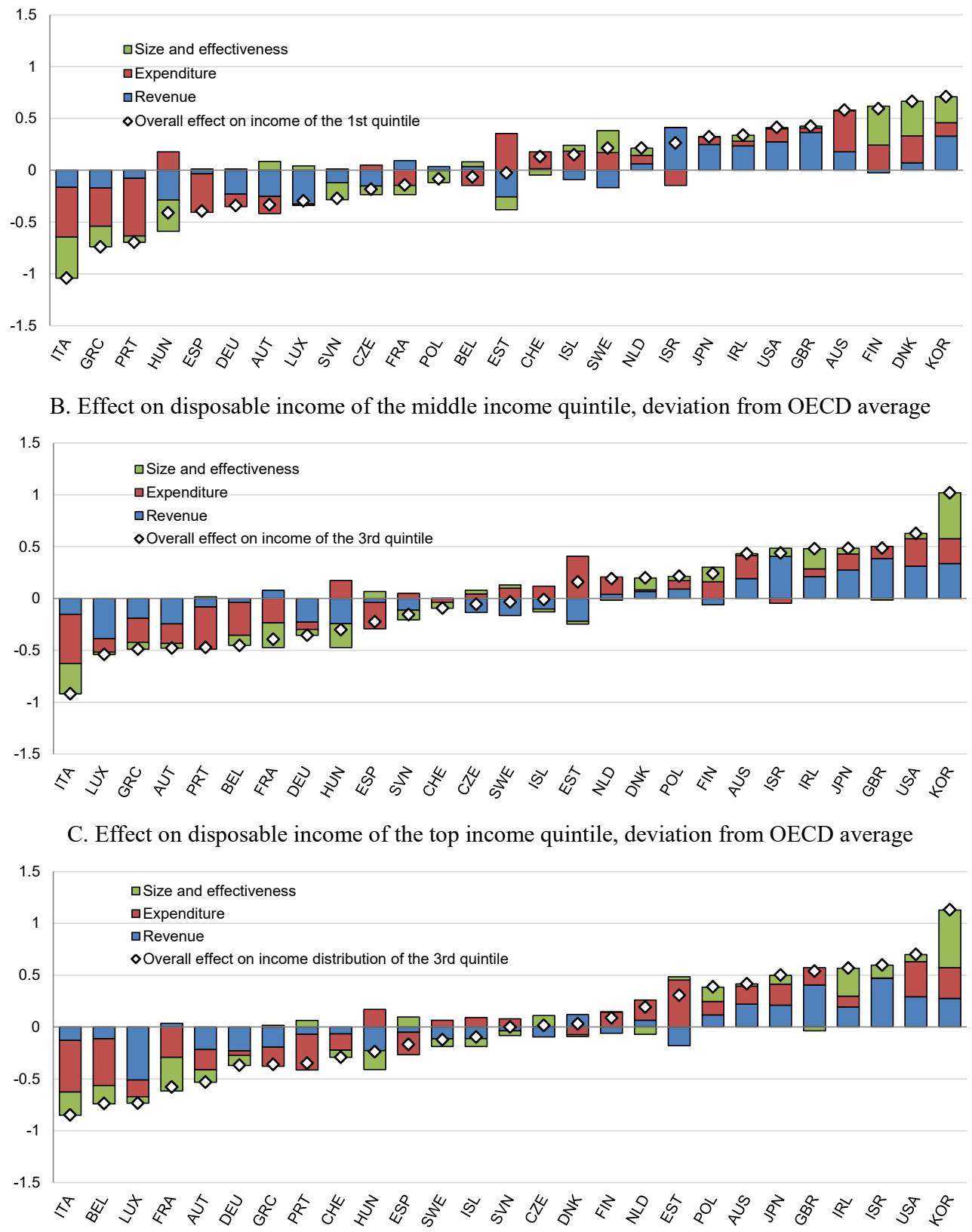

Note: The index uses output and income distribution elasticities (from the two papers quoted in the source) and the most recent detailed public finance data (2014-16) to compare across countries how the structure of spending and revenue as well as the size and perceived effectiveness of government influence household disposable incomes. The index is scaled to be equal to 1 in the country where the simulated effect on output per capita is furthest above the OECD average. The indices for the three quintiles shown (Panels A, B and C) and output per capita (Figure 14) all have the same scale so that they can be compared across quintiles and countries. The estimates come from panel regressions covering $34 \mathrm{OECD}$ countries over 1981-2014 (or fewer observations see Annex B). This chart only shows countries where all variables are available to ensure comparability.

Source: Authors' calculations based on (Akgun, Cournède and Fournier, 2017 ${ }_{[6]}$; Fournier and Johansson, 2016 ${ }_{[3]}$ ).

StatLink 젬 http://dx.doi.org/10.1787/888933887823 


\subsection{Two examples illustrating how the framework can be used to quantify public finance shifts}

\subsubsection{Cutting subsidies to reduce the tax wedge on below-average incomes}

The investigations point to many potential benefits and a possible risk of reducing public subsidies to fund a cut in the labour tax wedge on below-average earnings:

- Reducing subsidies and cutting the tax wedge on below-average earnings are two changes in public finance settings that the investigations have linked to gains in output per capita.

- A reform that reduces subsidies to fund a cut in the tax wedge on low earnings will in addition lower government size, a change which offers potential for additional output gains (except in countries where government effectiveness is very high).

- On the distributional side, easing the labour tax wedge on below-average earnings flattens the disposable income distribution.

- On the other hand, a cut in public subsidies can imply greater disposable income inequality.

The estimates, which allow quantifying the overall effects from all these channels, point to effects that can be expected to be positive across the distribution with particularly large gains for low income earners. For instance, a $1 / 2$ per cent of GDP cut in production subsidies used to fund a same-sized cut in the labour tax wedge on below-average earnings is simulated to boost the incomes of the poorest ten per cent of the population by $15 \%$ on average across OECD countries (Figure 16). The rest of the population also benefits substantially through the output channel, with the simulations showing a $11 \%$ increase for the top half of the income distribution.

The simulated effects of such a reform vary considerably across countries for two reasons:

- A $1 / 2$ per cent of GDP reduction in spending and revenue has different effects on longterm income levels depending on the effectiveness of governments (Fournier and Johansson, 2016 $[3]$ ).

- A $1 / 2$ per cent of GDP spending cut permits reductions in the below-average labour tax wedge that considerably differ across countries depending on how close their current wedge lies to the turning point of the rate-revenue relationship. Analyses undertaken as part of this project have indeed indicated that increases in the effective rate of the labour tax wedge stop generating additional revenue above a certain point, which depends on country characteristics (Akgun, Bartolini and Cournède, 2017 $7_{[5]}$ ). Consequently, an amount of $1 / 2$ per cent of GDP offer potential to fund very large cuts in the effective labour tax wedge in countries that are close to the revenue-maximising point (Figure 17). In turn, such large cuts in the effective rate of the labour tax wedge can translate into large gains in output per capita and larger disposable income gains for those directly targeted. ${ }^{4}$

4. The uncertainty surrounding the estimation of rate-revenue relationships, especially near the peak, implies that the size of the reported estimates of the rate changes associated with a $1 / 2$ of GDP revenue reduction should be taken with caution for countries in the region of the peak (Austria, Belgium and France). Notwithstanding this uncertainty about the precise size of the change, it remains clear that reducing revenue by $1 / 2$ of GDP allows a large cut in tax rates in countries where tax rates stand close to the peak of the rate-revenue relationship. 
Figure 16. Easing the labour tax wedge on below-average earnings funded by a cut in subsidies can boost incomes across the distribution

Illustrative simulated percentage change in household disposable income after 20 years

A. Bottom Quintile

40

30

20

10

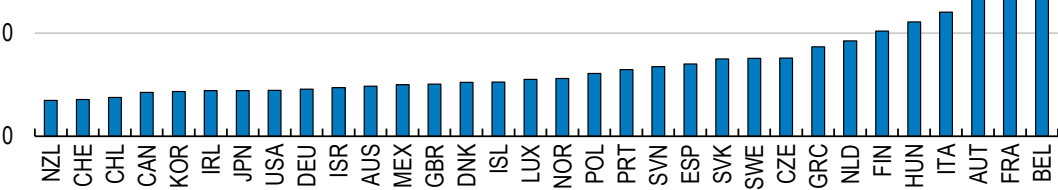

B. Middle Quintile
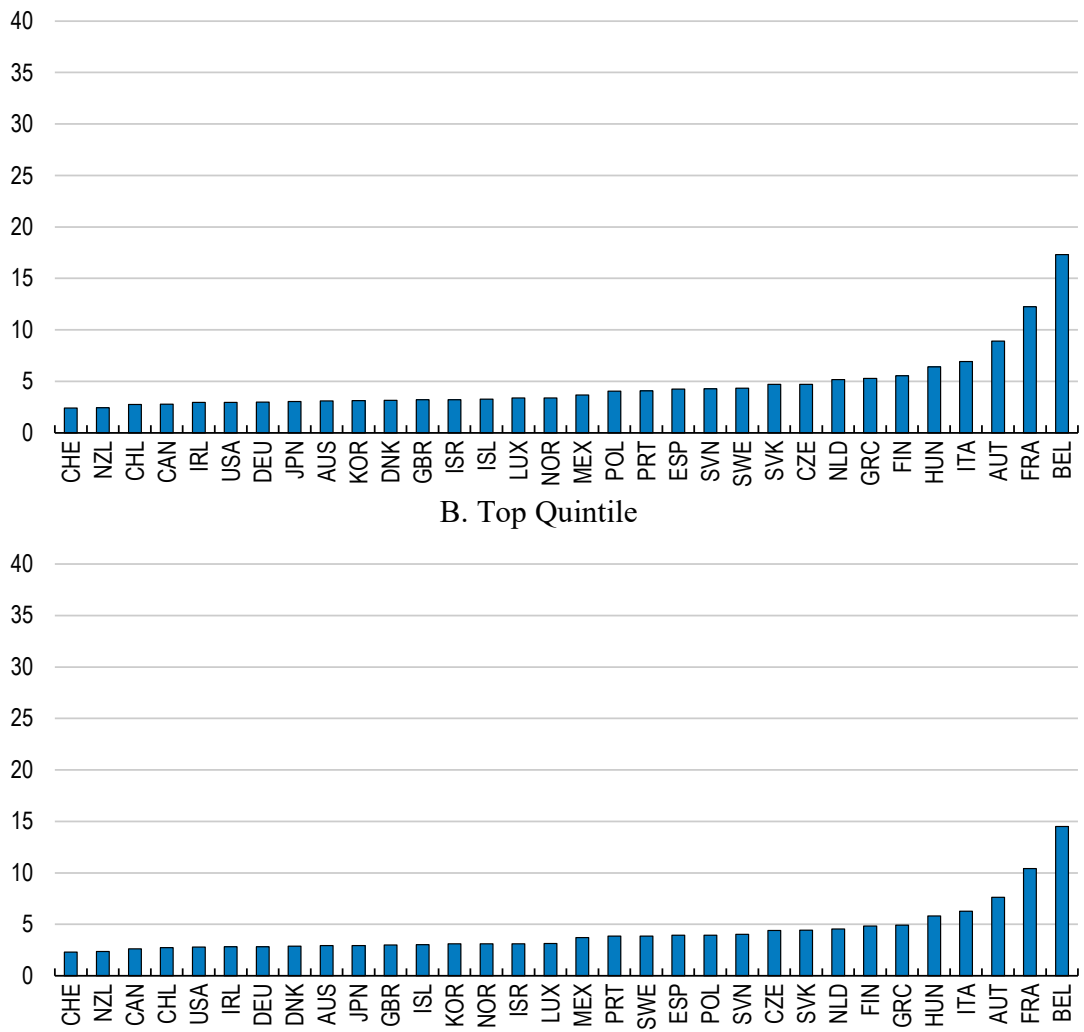

Note: The chart shows the long-term simulated effect of reducing public subsidies by $1 / 2$ per cent of GDP and reducing the labour tax wedge on below-average earnings so that personal income tax revenues also fall by $1 / 2$ per cent of GDP. The simulated effects correspond to what can be expected based on the observed experience of OECD countries: the effects of a reform in a given country can differ depending on the design of the reform and on country specificities that the regressions may not capture. The three papers referenced in the source present the underlying estimates in detail.

Source: Authors' calculations based on (Akgun, Cournède and Fournier, 2017 $[6]$; Fournier and Johansson, 2016 ${ }_{[3]}$; Akgun, Bartolini and Cournède, 2017 $[5]$ ).

StatLink त्ञात्र http://dx.doi.org/10.1787/888933887842 
Figure 17. Relatively limited resources can fund large cuts in the effective rate of the labour tax wedge on below-average earnings in countries close to the revenue-maximising point

Illustrative simulated long-term percentage change in the effective rate of the labour tax wedge on below-average earnings that reduces tax receipts by $1 / 2$ per cent of GDP

30

20

10

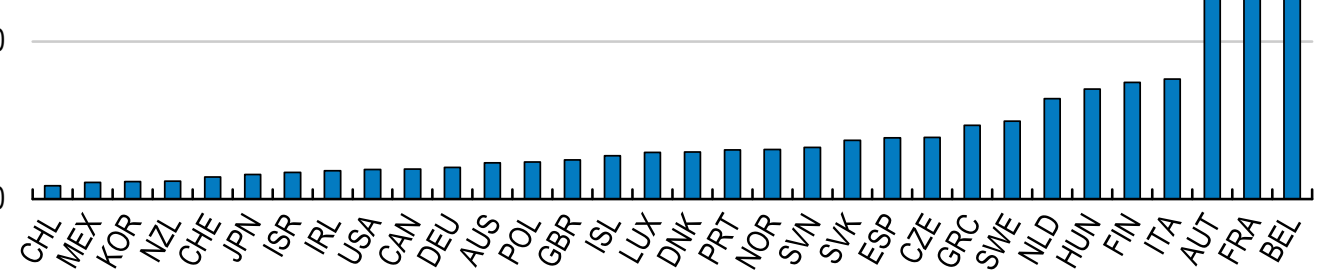

Note: The estimates are based on estimated rate-revenue relationships that depend on country characteristics. Source: Authors' calculations based on (Akgun, Bartolini and Cournède, $2017_{[5]}$ ).

StatLink 개내 http://dx.doi.org/10.1787/888933887861

\subsubsection{Shifting the burden of taxation away from low-paid labour towards environmental taxes}

The empirical results also allow quantifying the impacts by income group of environmental tax reform that couples higher environmentally related levies with tax cuts for low-income workers. Reforms of this nature have often been recommended to ensure environmental benefits while tackling perceived adverse social side-effects (OECD, $\left.2017_{[75]}\right)$. Indeed, the above analysis suggests that raising environmentally related taxes is likely to be growth neutral but may entail adverse distributional effects. However, reducing taxes for low-income earners, while raising environmental taxes can be anticipated to raise disposable incomes for all, with a greater effect on low income earners. The quantitative results of the analyses presented in this report enable putting together these various impacts so as to assess net effects, based on the average response to tax changes observed across OECD countries over past decades.

The simulations point to substantial positive effects on disposable incomes, which are particularly large for low-income earners (Figure 18). The positive effects of such a shift on average incomes, which these simulations show on the basis of empirical estimates, are consistent with model-based simulations (Bussière et al., 2017 $7_{[76]}$ ). The result that the shift is likely to produce higher disposable incomes for all across the distribution illustrates that the positive effects of cutting the labour tax wedge faced by low-income earners on both output per capita and income equality dwarf the small negative effects on disposable income of raising environmentally related taxes. Furthermore, higher pollution taxes can produce significant environmental benefits $\left(\mathrm{OECD}, 2005_{[77]}\right)$, underlining the benefits of integrated tax reforms (Brys et al., 2016 $6_{[7]}$ ). 
Figure 18. Shifting taxation away from low-paid labour towards environmental taxes can generate economic and distributional benefits in addition to improving the environment

Simulated percentage change in household disposable income after 20 years

A. Bottom quintile

40

30

20

10

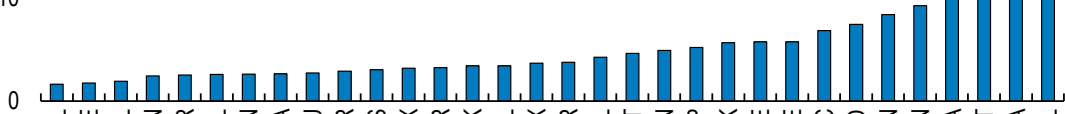

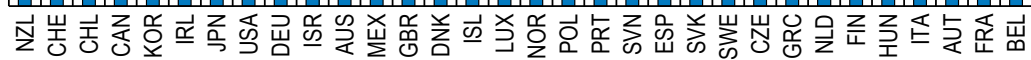

B. Middle quintile

40

30

20

10

0 م, 0 .

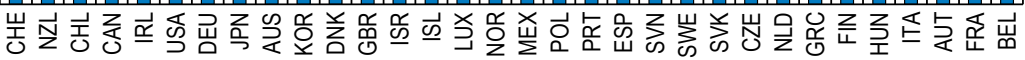

C. Top quintile

40

30

20

10

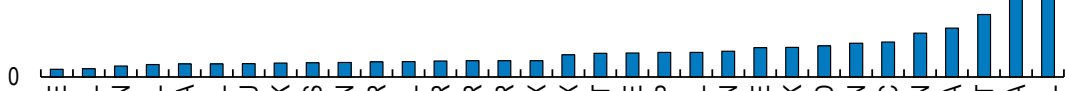

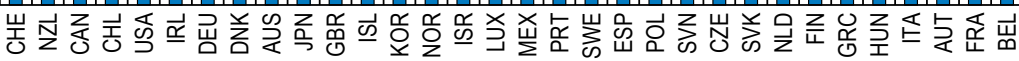

Note: The chart shows the long-term simulated effect of increasing receipts from environmentally related taxes by $1 / 2$ per cent of GDP and reducing the labour tax wedge on below-average earnings so that personal income tax revenues fall by $1 / 2$ per cent of GDP. The simulated effects correspond to what can be expected based on the observed experience of OECD countries: the effects of a reform in a given country can differ depending on the design of the reform and on country specificities that the regressions may not capture. The two papers referenced in the source present the underlying estimates. Source: Authors' calculations based on (Akgun, Cournède and Fournier, 2017 ${ }_{[6]}$; Akgun, Bartolini and Cournède, $2017_{[5]}$ ).

StatLink 제으 http://dx.doi.org/10.1787/888933887880 


\section{Annex A. Supplementary information on the analytical framework}

\section{Analytical framework}

The empirical investigations start with regressions in two steps:

1. Regressions estimate how the distribution of income (household disposable income in each decile) responds to changes in public finance policy (Channel 2 in Figure A. 1 and average output (Channel 3 on Figure A. 1) These regressions relate household disposable income in each decile to average income, spending and taxation indicators and other controls including time and country fixed-effects (Akgun, Cournède and Fournier, 2017[6]; Fournier and Johansson, 2016 $6_{[3]}$ ). They use an estimation strategy that takes into account the non-stationary nature of income levels (Stock et al., 1993 [78]; Saikkonen, 1991 [79]; Phillips and Loretan, $\left.1991_{[80]}\right)$.

Figure A. 1 The analytical framework captures distributional and average effects
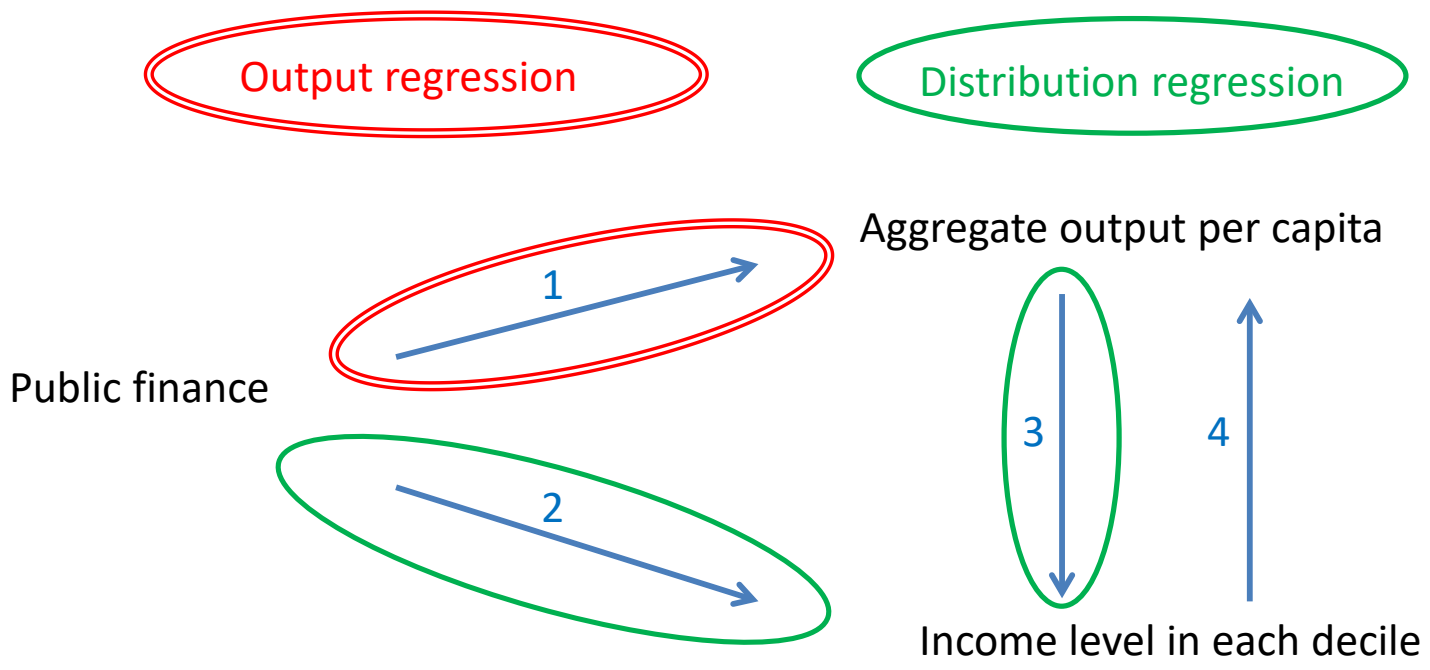

Source: (Fournier and Johansson, 2016 $6_{[3]}$; Akgun, Cournède and Fournier, 2017 $[6]$ ).

2. In a second step, regressions estimate the impact of fiscal policy instruments on average output per capita (Channel 1 on Figure A. 1). The estimations rely on an a production function framework, which relates an economy's output to the major inputs, such as labour and capital (Akgun, Cournède and Fournier, 2017 [6]; Fournier and Johansson, 2016 $\left.{ }_{[3]}\right]$. This approach is well established in the general econometric literature as well as more specifically in the field of public finance (Mankiw, Romer and Weil, 1992 ${ }_{[57]}$; Gemmell, Kneller and Sanz, 2014 ${ }_{[81]}$ ). The output regressions do not control for inequality, as checks indicated that 
inequality was not statistically significant, either directly or instrumenting with their own lags, in the sample for which the main public finance variables are available. The output regressions therefore include no inequality control: they will therefore pick up any effects transiting through Channel 4 (if present despite their lack of statistical significance in this sample) in reduced form without quantifying them.

The first and second steps are undertaken separately rather than simultaneously to take advantage of all the available information. Indeed, inequality indicators cover fewer years than the rest of the available statistics, so that implementing the second step (which deals with average output) allows benefiting from longer periods of experience. This choice enables better identifying output effects that take time to take hold: a particular case in point is education, where the feedthrough of changes in government interventions to output per capita is particularly long.

A final step, consisting of simulations, then combines the results from the two first steps. These simulations assess the effects of fiscal policy instruments on disposable income across the distribution given average income obtained from Step 1 with their effects on output per capita obtained from Step 2. Long-term effects on output per capita feed onefor-one into long-term average incomes (Hermansen, Ruiz and Causa, 2016 ${ }_{[12]}$ ). The fact that inequality does not enter the output regression means that the simulations can close the diagram by plugging the output impact from the output regression (Channel 1) into the inequality regression (Channels 2 and 3) directly without generating an outputinequality loop (that would otherwise arise between Channels 3 and 4).

\section{Sources of the tax and income indicators used in the empirical analysis}

The analysis relies on effective tax rates, inasmuch as comparable cross-country time series are available, and revenue-to-GDP ratios otherwise:

- OECD measures allow evaluating the marginal effective tax wedges on labour income for workers with different wage levels (OECD, 2017 $\left.{ }_{[82]}\right)$. The core empirical analysis uses marginal effective tax wedges for single individuals; however, the results are robust to this choice, because labour tax wedges for other family types are highly correlated with the ones for single individuals.

- For corporate income tax, the empirical analyses use marginal effective tax rates from the Oxford Centre on Business Taxation, which cover a wide range of OECD countries over an extended period of time (CBT, 2017 $[83])$. The OECD has compiled highly comparable measures of marginal effective rates of corporate income tax; however, these relate to 2015 and 2017, while the empirical framework underpinning this study requires an extended period of time to identify policy effects (OECD, 2018[84]).

- Statutory rates, which are taken from the OECD Tax Database (OECD, 2017 $7_{[85]}$ ), are used for value-added tax. Statutory rates apply to the majority of private consumption. However, their use means that the analysis does not capture the impact of reduced rates, for lack of sufficient data about the share of consumption to which they apply. This area represents an avenue for future research, as the levels and bases to which reduced rates apply can substantially vary over time and across countries, with potential implications for the effects of value-added tax on inclusive growth.

- Other taxes, which include environmental and property taxes, are measured by the amount of revenue they produce, as ratios to GDP (OECD, 2017[86]). 
The indicators of outcomes for household disposable income come from the OECD Income Distribution Database (OECD, 2016 [87]). They allow comparing changes in OECD countries on a comparable footing, in particular by using the same income concepts and the same methods to adjust for household size. Distributional statistics about real household disposable income, however, do not allow measuring effects on consumption inequality that transit through differences in saving choices or price levels across income groups. Regarding prices, the measure incorporates impacts that are common to all income groups, such as for instance overall shifts in the price level linked to a broad VAT reform, but not the effects of tax changes that have heterogeneous price implications across income groups. The reason is that time series of distributional price indices that reflect specificities of the consumption basket of each income group remain to be compiled. 
Annex B. Data coverage

Table B.1. Country and time coverage of main spending variables in the empirical analysis

\begin{tabular}{|c|c|c|c|c|}
\hline Country & Pensions & Family benefits & Subsidies & Investment \\
\hline AUS & n.a. & n.a. & $1985-2014$ & $1985-2014$ \\
\hline AUT & $1985-2014$ & $1990-2014$ & $1985-2014$ & $1985-2014$ \\
\hline BEL & $1985-2013$ & $1986-2013$ & $1985-2014$ & $1985-2014$ \\
\hline CAN & n.a. & n.a. & $1962-2014$ & $1962-2014$ \\
\hline CHE & $1985-2013$ & $1990-2013$ & $1985-2014$ & $1985-2014$ \\
\hline $\mathrm{CHL}$ & n.a. & n.a. & n.a. & n.a. \\
\hline CZE & $1998-2013$ & $1998-2013$ & $1998-2014$ & 1998-2014 \\
\hline DEU & $1991-2013$ & $1991-2013$ & $1991-2014$ & $1991-2014$ \\
\hline DNK & $1990-2014$ & $1986-2014$ & $1985-2014$ & $1985-2014$ \\
\hline ESP & $1985-2013$ & $1995-2013$ & $1985-2014$ & $1985-2014$ \\
\hline EST & $2001-2013$ & $2001-2013$ & $2001-2014$ & 2001-2014 \\
\hline FIN & $1990-2013$ & $1990-2013$ & $1990-2014$ & $1990-2014$ \\
\hline FRA & $1985-2013$ & $1986-2013$ & $1985-2014$ & $1985-2014$ \\
\hline GBR & $1990-2013$ & $1986-2013$ & $1985-2014$ & $1985-2014$ \\
\hline GRC & $2001-2013$ & $2001-2013$ & $1986-2014$ & 1988-2014 \\
\hline HUN & $1995-2013$ & $1996-2013$ & $1995-2014$ & $1995-2014$ \\
\hline IRL & $1986-2013$ & $1990-2013$ & $1986-2014$ & 1986-2014 \\
\hline ISL & $1991-2013$ & $1991-2013$ & $1991-2014$ & 1991-2014 \\
\hline $\mathrm{ISR}^{*}$ & 2006-2012 & 2006-2012 & $1995-2014$ & $1995-2014$ \\
\hline ITA & $1985-2013$ & $1986-2013$ & $1985-2014$ & $1985-2014$ \\
\hline JPN & $1990-2013$ & $1994-2013$ & $1990-2013$ & 1990-2014 \\
\hline KOR & $1996-2011$ & $1996-2011$ & $1985-2014$ & $1985-2014$ \\
\hline LUX & $1995-2013$ & $1996-2013$ & $1995-2014$ & $1995-2014$ \\
\hline MEX & n.a. & n.a. & $1995-2013$ & 2003-2014 \\
\hline NLD & $1985-2013$ & $1986-2013$ & $1985-2014$ & $1985-2014$ \\
\hline NOR & $1980-2013$ & $1980-2013$ & $1980-2014$ & $1980-2014$ \\
\hline NZL & n.a. & n.a. & $1989-2013$ & 1989-2014 \\
\hline POL & $1996-2013$ & $1997-2013$ & $1996-2014$ & 1996-2014 \\
\hline PRT & $1995-2013$ & $1986-2013$ & $1985-2014$ & $1985-2014$ \\
\hline SVK & $1996-2013$ & $1996-2013$ & $1996-2014$ & 1996-2014 \\
\hline SVN & $1999-2013$ & $1999-2013$ & $1999-2014$ & 1999-2014 \\
\hline SWE & $1985-2013$ & $1993-2013$ & $1985-2014$ & $1985-2014$ \\
\hline TUR & n.a. & n.a. & 2006-2011 & 2006-2014 \\
\hline USA & $1985-2012$ & 1986-2012 & $1985-2014$ & $1985-2014$ \\
\hline
\end{tabular}

Source: (Fournier and Johansson, 2016[3]).

* The statistical data for Israel are supplied by and under the responsibility of the relevant Israeli authorities. The use of such data by the OECD is without prejudice to the status of the Golan Heights, East Jerusalem and Israeli settlements in the West Bank under the terms of international law. 
Table B.2. Country and time coverage of main tax variables in the empirical analysis

\begin{tabular}{|c|c|c|c|c|c|c|}
\hline Country & $\begin{array}{l}\text { CIT marginal } \\
\text { effective rate }\end{array}$ & $\begin{array}{c}\text { PIT top } \\
\text { marginal rate }\end{array}$ & VAT statutory rate & Labour tax wedges & Property tax receipts & Environmental tax receipts \\
\hline AUS & $1988-2014$ & $1981-2014$ & $2000-2014$ & $2000-2014$ & $1980-2014$ & $1994-2013$ \\
\hline AUT & $1994-2014$ & $1981-2014$ & 1973-2014 & $2000-2014$ & $1980-2014$ & $1994-2013$ \\
\hline BEL & $1994-2014$ & $1981-2014$ & $1971-2014$ & $2000-2014$ & $1980-2014$ & $1994-2013$ \\
\hline CAN & $1999-2014$ & $1981-2014$ & $1991-2014$ & $2000-2014$ & $1980-2014$ & $1994-2013$ \\
\hline CHE & $1994-2014$ & $1981-2014$ & $1995-2014$ & $2000-2014$ & $1980-2014$ & $1994-2013$ \\
\hline $\mathrm{CHL}$ & $1996-2014$ & $2000-2014$ & $1975-2014$ & $2000-2014$ & $1990-2014$ & \\
\hline CZE & $2002-2014$ & $1993-2014$ & $1993-2014$ & $2000-2014$ & $1997-2014$ & $1994-2013$ \\
\hline DEU & $1990-2014$ & $1981-2014$ & $1968-2014$ & $2000-2014$ & $1980-2014$ & $1994-2013$ \\
\hline DNK & $1992-2014$ & $1981-2014$ & $1967-2014$ & $2000-2014$ & $1980-2014$ & $1994-2013$ \\
\hline ESP & $1996-2014$ & $1981-2014$ & $1986-2014$ & $2000-2014$ & $1980-2014$ & $1994-2013$ \\
\hline EST & $1994-2014$ & $2000-2014$ & $1992-2014$ & $2000-2014$ & $2000-2014$ & $1995-2013$ \\
\hline FIN & $1992-2014$ & $2000-2014$ & $1994-2014$ & $2000-2014$ & $1980-2014$ & $1994-2013$ \\
\hline FRA & $1990-2014$ & $1981-2014$ & $1968-2014$ & $2000-2014$ & $1980-2014$ & $1994-2013$ \\
\hline GBR & $1990-2014$ & $1981-2014$ & $1973-2014$ & $2000-2014$ & $1980-2014$ & $1994-2013$ \\
\hline GRC & $1998-2014$ & $1981-2014$ & $1987-2014$ & $2000-2014$ & $1985-2014$ & $1994-2013$ \\
\hline HUN & $1994-2014$ & $1989-2014$ & $1988-2014$ & $2000-2014$ & $1996-2014$ & $1995-2013$ \\
\hline IRL & $1994-2014$ & $1981-2014$ & $1972-2014$ & $2000-2014$ & $1986-2014$ & $1994-2013$ \\
\hline ISL & $1995-2014$ & $2000-2014$ & $1990-2014$ & $2000-2014$ & $1980-2014$ & $1994-2013$ \\
\hline $\mathrm{ISR}^{*}$ & $1998-2014$ & $2000-2014$ & $1976-2014$ & $2000-2014$ & $1995-2014$ & $1995-2013$ \\
\hline ITA & $1990-2011$ & $1981-2014$ & $1973-2014$ & $2000-2014$ & $1980-2014$ & $1994-2013$ \\
\hline JPN & $1983-2014$ & $2000-2014$ & $1989-2014$ & $2000-2014$ & $1980-2014$ & $1994-2013$ \\
\hline KOR & $1999-2014$ & $2000-2014$ & $1977-2014$ & $2000-2014$ & $1980-2014$ & $1994-2013$ \\
\hline LUX & $1999-2014$ & $2000-2014$ & $1970-2014$ & $2000-2014$ & $1996-2014$ & $1994-2013$ \\
\hline LVA & & & $2000-2014$ & $2000-2014$ & $1996-2014$ & \\
\hline MEX & $1999-2014$ & $1981-2014$ & $1980-2014$ & $2000-2014$ & $1995-2014$ & $2003-2013$ \\
\hline NLD & $1998-2014$ & $1981-2014$ & $1969-2014$ & $2000-2014$ & $1980-2014$ & $1994-2013$ \\
\hline NOR & $1992-2014$ & $1981-2014$ & $1970-2014$ & $2000-2014$ & $1980-2014$ & $1994-2013$ \\
\hline NZL & $1999-2014$ & $1981-2014$ & $1987-2014$ & $2000-2014$ & $1989-2014$ & $1994-2013$ \\
\hline POL & $1994-2014$ & $1992-2014$ & $1993-2014$ & $2000-2014$ & $1997-2014$ & $1995-2013$ \\
\hline PRT & $1994-2014$ & $1981-2014$ & $1986-2014$ & $2000-2014$ & $1980-2014$ & $1994-2013$ \\
\hline SVK & & $1993-2014$ & $1993-2014$ & $2000-2014$ & $1996-2014$ & $1995-2013$ \\
\hline SVN & $1995-2014$ & $2000-2014$ & 1999-2014 & $2000-2014$ & 1999-2014 & $1995-2013$ \\
\hline SWE & $1992-2014$ & $1981-2014$ & 1969-2014 & $2000-2014$ & $1980-2014$ & $1994-2013$ \\
\hline TUR & $1998-2014$ & $2000-2014$ & $1985-2014$ & $2000-2014$ & $1995-2014$ & $2006-2011$ \\
\hline USA & $1999-2014$ & $1981-2014$ & & $2000-2014$ & $1980-2014$ & $1994-2013$ \\
\hline
\end{tabular}

* The statistical data for Israel are supplied by and under the responsibility of the relevant Israeli authorities. The use of such data by the OECD is without prejudice to the status of the Golan Heights, East Jerusalem and Israeli settlements in the West Bank under the terms of international law. 


\section{References}

Aaberge, R. and L. Flood (2013), "U.S. versus Sweden: The Effect of Alternative In-Work Tax Credit Policies on Labour Supply of Single Mothers", IZA Discussion Papers, https://ideas.repec.org/p/iza/izadps/dp7706.html (accessed on 11 December 2017).

Acemoglu, D. and S. Johnson (2007), "Disease and Development: The Effect of Life Expectancy on Economic Growth", Journal of Political Economy, Vol. 115/6, https://economics.mit.edu/files/4478 (accessed on 19 December 2017).

Afonso, A. and J. Jalles (2011), "Economic Performance and Government Size", ECB Working Papers, No. 1399, ECB, https://papers.ssrn.com/sol3/papers.cfm?abstract id $=1950570$ (accessed on 21 December 2017).

Aghion, P. et al. (2017), “Tax Simplicity and Heterogeneous Learning”, National Bureau of Economic Research Working Paper Series, Vol. No. 24049, http://dx.doi.org/10.3386/w24049.

Aghion, P., P. Howitt and F. Murtin (2010), "The Relationship Between Health and Growth: When Lucas Meets Nelson-Phelps", Review of Economics and Institutions, Vol. 2/1, http://dx.doi.org/10.5202/rei.v2i1.22.

Akgun, O., D. Bartolini and B. Cournède (2017), "The Capacity of Governments to Raise Taxes", OECD Economics Department Working Papers, No. 1407, OECD Publishing, Paris, http://dx.doi.org/10.1787/6bee2df9-en.

Akgun, O., B. Cournède and J. Fournier (2017), "Effects of the Tax Mix on Inequality and Growth", OECD Economics Department Working Papers, No. 1447, OECD Publishing, Paris, http://dx.doi.org/10.1787/c57eaa14-en.

Arnold, J. (2008), "Do Tax Structures Affect Aggregate Economic Growth?: Empirical Evidence from a Panel of OECD Countries", OECD Economics Department Working Papers, No. 643, OECD Publishing, Paris, http://dx.doi.org/10.1787/236001777843.

Arnold, J. et al. (2011), "Tax Policy for Economic Recovery and Growth", The Economic Journal, Vol. 121/550, pp. F59-F80, http://dx.doi.org/10.1111/j.1468-0297.2010.02415.x.

Bartolini, D. (2018), "Firms at the Productivity Frontier Enjoy Lower Effective Taxation", OECD Economics Department Working Papers, No. 1475, OECD Publishing, forthcoming.

Bhargava, A. et al. (2001), Journal of Health Economics., North-Holland, https://econpapers.repec.org/article/eeejhecon/v 3a20 3ay 3a2001 3ai 3a3 3ap 3a423440.htm (accessed on 19 December 2017).

Bloch, D. et al. (2016), "Trends in Public Finance: Insights from a New Detailed Dataset", OECD Economics Department Working Papers, No. 1345, OECD Publishing, Paris, http://dx.doi.org/10.1787/4d3d8b25-en. 
Blöchliger, H. et al. (2015), “The Stabilisation Properties of Immovable Property taxation: Evidence from OECD countries", OECD Economics Department Working Papers, No. 1237, OECD Publishing, Paris, http://dx.doi.org/10.1787/5js0cqq93djg-en.

Blundell, R. et al. (2009), "Optimal Income Taxation of Lone Mothers: An Empirical Comparison of the UK and Germany", The Economic Journal, Vol. 119/535, pp. F101-F121, http://dx.doi.org/10.1111/j.1468-0297.2008.02261.x.

Boarini, R. et al. (2016), "Multi-dimensional Living Standards: A Welfare Measure Based on Preferences", OECD Statistics Working Papers, No. 2016/5, OECD Publishing, Paris, http://dx.doi.org/10.1787/5jlpq7qvxc6f-en.

Brandt, N. (2014), "Greening the Property Tax", OECD Working Papers on Fiscal Federalism, No. 17, OECD Publishing, Paris, http://dx.doi.org/10.1787/5jz5pzw9mwzn-en.

Brewer, M. et al. (2006), "Did Working Families' Tax Credit Work? The Impact of In-work Support on Labour Supply in Great Britain", Labour Economics, Vol. 13/6, pp. 699-720, http://dx.doi.org/10.1016/J.LABECO.2005.11.002.

Brys, B. et al. (2016), "Tax Design for Inclusive Economic Growth", OECD Taxation Working Papers, No. 26, OECD Publishing, Paris, http://dx.doi.org/10.1787/5jlv74ggk0g7-en.

Bussière, M. et al. (2017), "Can Fiscal Budget-Neutral Reforms Stimulate Growth? Model-Based Results", Banque de France Working Paper, No. 625, https://publications.banquefrance.fr/sites/default/files/medias/documents/dt625.pdf (accessed on 06 April 2018).

Causa, O., A. Vindics and O. Akgun (2018), "An Empirical Investigation on the Drivers of Income Redistribution across OECD Countries", OECD Economics Department Working Papers, No. 1488, OECD Publishing.

Causa, O. and M. Hermansen (2017), "Income Redristribution through Taxes and Transfers across OECD Countries", OECD Economics Department Working Papers, No. 1453, OECD Publishing.

CBT (2017), Tax Database: Data Description, Oxford Center for Business Taxation, Oxford, http://bit.ly/2xtXmeo.

Cronin, J. et al. (2013), "Distributing the Corporate Income Tax: Revised U.S. Treasury Methodology", National Tax Journal, Vol. 66/1, pp. 239-262, https://ideas.repec.org/a/ntj/journl/v66y2013i1p239-62.html (accessed on 14 December 2017).

de la Maisonneuve, C. and J. Oliveira Martins (2014), "The Future of Health and Long-term Care Spending", OECD Journal: Economic Studies, Vol. 2014/1, http://dx.doi.org/10.1787/eco studies-2014-5jz0v44s66nw.

Diamond, P. and J. Mirrlees (1971), Optimal Taxation and Public Production II: Tax Rules, American Economic Association, http://dx.doi.org/10.2307/1813425.

Diamond, P. and E. Saez (2011), "The Case for a Progressive Tax: From Basic Research to Policy Recommendation", Journal of Economic Perspectives, Vol. 25/4, pp. 165-190, http://dx.doi.org/10.1257/jep.25.4.165.

Disney, R. (2004), Are Contributions to Public Pension Programmes a Tax on Employment?, https://papers.ssrn.com/sol3/papers.cfm?abstract id=559626 (accessed on 15 December 2017). 
Djankov, S. et al. (2010), "The Effect of Corporate Taxes on Investment and Entrepreneurship", American Economic Journal: Macroeconomics, Vol. 2/3, pp. 31-64, http://dx.doi.org/10.1257/mac.2.3.31.

Duval, R. (2004), "Retirement Behaviour in OECD Countries: Impact of Old-Age Pension Schemes and other Social Transfer Programmes", OECD Economic Studies, Vol. 2003/2, http://dx.doi.org/10.1787/eco_studies-v2003-art8-en.

Eichengreen, B. (1990), "The Capital Levy in Theory and Practice", in Dornbusch, R. and M. Draghi (eds.), Public Debt Management, Cambridge University Press, Cambridge, http://dx.doi.org/10.1017/CBO9780511628528.014.

European Commission (2017), "Impact of Fiscal Policy on Income Redistribution", in Report on Public Finances in EMU.

Feld, L. and J. Heckemeyer (2011), "FDI and Taxation: A Meta-Study", Journal of Economic Surveys, Vol. 25/2, pp. 233-272, http://dx.doi.org/10.1111/j.1467-6419.2010.00674.x.

Feldstein, M. (1996), “The Missing Piece in Policy Analysis: Social Security Reform”, American Economic Review, Vol. 86/2, pp. 1-14, http://www.jstor.org/stable/2118087 (accessed on 09 February 2018).

Finkelstein, M. et al. (2003), "Relation between Income, Air Pollution and Mortality: A Cohort Study", CMAJ : Canadian Medical Association Journal, Vol. 169/5, pp. 397-402, http://www.ncbi.nlm.nih.gov/pubmed/12952800 (accessed on 15 December 2017).

Flues, F. and A. Thomas (2015), "The Distributional Effects of Energy Taxes", OECD Taxation Working Papers, No. 23, OECD Publishing, Paris, http://dx.doi.org/10.1787/5js1qwkqqrbven.

Fournier, J. (2016), “The Positive Effect of Public Investment on Potential Growth", OECD Economics Department Working Papers, No. 1347, OECD Publishing, Paris, http://dx.doi.org/10.1787/15e400d4-en.

Fournier, J. and A. Johansson (2016), "The Effect of the Size and the Mix of Public Spending on Growth and Inequality”, OECD Economics Department Working Papers, No. 1344, OECD Publishing, Paris, http://dx.doi.org/10.1787/f99f6b36-en.

Fournier, J. and I. Koske (2012), "The Determinants of Earnings Inequality: Evidence from Quantile Regressions", OECD Journal: Economic Studies, Vol. 2012/1, http://dx.doi.org/10.1787/eco studies-2012-5k8zs3twbrd8.

Fuest, C., A. Peichl and S. Siegloch (2018), "Do Higher Corporate Taxes Reduce Wages? Micro Evidence from Germany", American Economic Review, Vol. 108/2, pp. 393-418, http://dx.doi.org/10.1257/aer.20130570.

Fullerton, D. and G. Metcalf (2002), “Tax Incidence”, Handbook of Public Economics, Vol. 4, pp. 1787-1872, http://dx.doi.org/10.1016/S1573-4420(02)80005-2.

Garcia-Sanchez, I., B. Cuadrado-Ballesteros and J. Frias-Aceituno (2013), "Determinants of Government Effectiveness", International Journal of Public Administration, Vol. 36/8, pp. 567-577, http://dx.doi.org/10.1080/01900692.2013.772630.

Gemmell, N., R. Kneller and I. Sanz (2014), "The Growth Effects of Tax Rates in the OECD", Canadian Journal of Economics/Revue canadienne d'économique, Vol. 47/4, pp. 1217-1255, http://dx.doi.org/10.1111/caje.12105. 
Hajkova, D. et al. (2007), "Taxation and Business Environment as Drivers of Foreign Direct Investment in OECD Countries", OECD Economic Studies, Vol. 2006/2, http://dx.doi.org/10.1787/eco studies-v2006-art8-en.

Hansson, A. (2010), "Is the Wealth Tax Harmful to Economic Growth?", World Tax Journal February.

Hanushek, E. and L. Woessmann (2010), "Chapter 2 - The Economics of International Differences in Educational Achievement", Handbook of the Economics of Education, Vol. 3, pp. 89-200, http://dx.doi.org/10.1016/B978-0-444-53429-3.00002-8.

Hartwig, J. (2010), "Is Health Capital Formation Good for Long-term Economic Growth? - Panel Granger-causality Evidence for OECD Countries", Journal of Macroeconomics, Vol. 32/1, pp. 314-325, https://ideas.repec.org/a/eee/jmacro/v32y2010ilp314-325.html (accessed on 19 December 2017).

Hermansen, M., N. Ruiz and O. Causa (2016), "The Distribution of the Growth Dividends", OECD Economics Department Working Papers, No. 1343, OECD Publishing, Paris, http://dx.doi.org/10.1787/7c8c6cc1-en.

Høj, A., M. Jørgensen and P. Schou (2018), "Land Tax Changes and Full Capitalisation”, Fiscal Studies, Vol. 39/2, pp. 365-380, http://dx.doi.org/10.1111/1475-5890.12163.

IMF (2013), Fiscal Monitor: Taxing Times, IMF, http://www.imf.org/en/Publications/FM/Issues/2016/12/31/Taxing-Times.

Johansson, A. (2016), "Public Finance, Economic Growth and Inequality: A Survey of the Evidence", OECD Economics Department Working Papers, No. 1346, OECD Publishing, Paris, http://dx.doi.org/10.1787/094bdaa5-en.

Joumard, I. et al. (2008), "Health Status Determinants: Lifestyle, Environment, Health Care Resources and Efficiency", OECD Economics Department Working Papers, No. 627, OECD Publishing, Paris, http://dx.doi.org/10.1787/240858500130.

Joumard, I., M. Pisu and D. Bloch (2012), "Tackling Income Inequality: The Role of Taxes and Transfers", OECD Journal: Economic Studies, pp. 37-70, http://dx.doi.org/10.1787/19952856.

Kaplow, L. (1996), "How Tax Complexity and Enforcement Affect the Equity and Efficiency of the Income Tax", National Tax Journal, Vol. 49/1, http://www.ntanet.org/NTJ/49/1/ntjv49n01p135-50-how-tax-complexity-enforcement.pdf?v=\%CE\%B1.

Kaufmann, D., A. Kraay and M. Mastruzzi (2011), "The Worldwide Governance Indicators: Methodology and Analytical Issues", Hague Journal on the Rule of Law, Vol. 3/3, pp. 220246, http://dx.doi.org/10.1017/S1876404511200046.

Kohl, R. and P. O'Brien (1998), "The Macroeconomics of Ageing, Pensions and Savings: A Survey", OECD Economics Department Working Papers, No. 200, OECD Publishing, Paris, http://dx.doi.org/10.1787/687160618113.

Layard, R. (2003), Happiness: Has Social Science a Clue? Lecture 1: What is Happiness? Are We Getting Happier?, Lionel Robbins memorial lecture series, London, http://eprints.1se.ac.uk/47425/ (accessed on 19 December 2017).

Lefèbvre, M. (2007), "The Redistributive Effects of Pension Systems in Europe: A Survey of Evidence", Luxembourg Income Study Working Paper Series, http://www.lisdatacenter.org/wps/liswps/457.pdf (accessed on 13 December 2017). 
Lizarazo Ruiz, S., A. Peralta-Alva and D. Puy (2017), "Macroeconomic and Distributional Effects of Personal Income Tax Reforms: A Heterogenous Agent Model Approach for the U.S.”, IMF Working Papers, No. 17/192, https://papers.ssrn.com/sol3/papers.cfm?abstract $\mathrm{id}=3124374 \&$ download=yes (accessed on 29 March 2018).

Mankiw, N., D. Romer and D. Weil (1992), "A Contribution to the Empirics of Economic Growth”, The Quarterly Journal of Economics, Vol. 107/2, pp. 407-437, http://dx.doi.org/10.2307/2118477.

Matikka, T. (2017), "Elasticity of Taxable Income: Evidence from Changes in Municipal Income Tax Rates in Finland", The Scandinavian Journal of Economics, Vol. 120/3, pp. 943-973, http://dx.doi.org/10.1111/sjoe.12236.

Mills, E. (1998), “The Economic Consequences of a Land Tax", in Netzer, D. (ed.), Land Value Taxation, Lincoln Institute of Land Policy.

Norregaard, J. et al. (2013), "Taxing Immovable Property: Revenue Potential and Implementation Challenges", IMF Working Paper, No. 13/129, http://www.imf.org/external/pubs/ft/wp/2013/wp13129.pdf (accessed on 14 December 2017).

Oates, W. and R. Schwab (1997), "The Impact of Urban Land Taxation: The Pittsburgh Experience", National Tax Journal, Vol. 50/1, pp. 1-21, https://www.ntanet.org/NTJ/50/1/ntjv50n01p1-21-impact-urban-land-taxation.pdf? $\mathrm{v}=\% \mathrm{CE} \% \mathrm{~B} 1 \& \mathrm{r}=7712342634855462$ (accessed on 14 December 2017).

OECD (2018), Corporate Tax Statistics, OECD Publishing, forthcoming.

OECD (2018), World Class: How to Build a 21st-Century School System, Strong Performers and Successful Reformers in Education, OECD Publishing, Paris, http://dx.doi.org/10.1787/9789264300002-en.

OECD (2017), Education at a Glance 2017: OECD Indicators, OECD Publishing, Paris, http://dx.doi.org/10.1787/eag-2017-en.

OECD (2017), Environmental Fiscal Reform: Progress, Prospects and Pitfalls, OECD Report for the G7 Environment Ministers, https://www.oecd.org/tax/tax-policy/environmental-fiscalreform-G7-environment-ministerial-meeting-june-2017.pdf (accessed on 28 March 2018).

OECD (2017), Getting Infrastructure Right: The Ten Key Governance Challenges and Policy Options, OECD, https://www.oecd.org/gov/getting-infrastructure-right.pdf (accessed on 19 December 2017).

OECD (2017), Government at a Glance 2017, OECD Publishing, Paris, http://dx.doi.org/10.1787/gov_glance-2017-en.

OECD (2017), National Accounts of OECD Countries, Volume 2017 Issue 1: Main Aggregates, OECD Publishing, Paris, http://dx.doi.org/10.1787/na_ma_dt-v2017-1-en.

OECD (2017), OECD Economic Outlook, Volume 2017 Issue 2, OECD Publishing, Paris, http://dx.doi.org/10.1787/eco_outlook-v2017-2-en.

OECD (2017), OECD Income Distribution Database (IDD): Gini, Poverty, Income. Methods and Concepts, OECD Publishing, http://www.oecd.org/social/income-distribution-database.htm (accessed on 15 December 2017).

OECD (2017), OECD Tax Database, http://www.oecd.org/tax/tax-policy/tax-database.htm. 
OECD (2017), Preventing Ageing Unequally, OECD Publishing, Paris, http://dx.doi.org/10.1787/9789264279087-en.

OECD (2017), Revenue Statistics: 1965-2016, OECD Publishing, Paris, http://dx.doi.org/10.1787/9789264283183-en.

OECD (2017), Tackling Wasteful Spending on Health, OECD Publishing, Paris, http://dx.doi.org/10.1787/9789264266414-en.

OECD (2017), Taxing Wages 2017, OECD Publishing, Paris, http://dx.doi.org/10.1787/tax wages-2017-en.

OECD (2017), The Funding of School Education: Connecting Resources and Learning, OECD Publishing, http://dx.doi.org/10.1787/9789264276147-en.

OECD (2016), Digital Government Toolkit, OECD Publishing, http://www.oecd.org/governance/digital-government/toolkit/ (accessed on 19 December 2017).

OECD (2016), "Income Distribution (Edition 2016)", OECD Social and Welfare Statistics (database), http://dx.doi.org/10.1787/6bdab994-en. (accessed on 30 November 2017)

OECD (2016), OECD Economic Outlook, Volume 2016 Issue 2, OECD Publishing, Paris, http://dx.doi.org/10.1787/eco_outlook-v2016-2-en.

OECD (2016), "Reforming the Tax on Immovable Property", in Fiscal Federalism 2016: Making Decentralisation Work, OECD Publishing, Paris, http://dx.doi.org/10.1787/9789264254053-5en.

OECD (2015), OECD Recommendation of the Council on Public Procurement, https:/www.oecd.org/gov/ethics/OECD-Recommendation-on-Public-Procurement.pdf (accessed on 19 December 2017).

OECD (2015), Pensions at a Glance 2015: OECD and G20 indicators, OECD Publishing, Paris, http://dx.doi.org/10.1787/pension_glance-2015-en.

OECD (2014), Recommendation of the Council on Effective Public Investment across Levels of Government, http://www.oecd.org/regional/regional-policy/Principles-Public-Investment.pdf (accessed on 19 December 2017).

OECD (2013), Fiscal Federalism 2014: Making Decentralisation Work, OECD Publishing, Paris, [104] http://dx.doi.org/10.1787/9789264204577-en.

OECD (2013), PISA 2012 Results: What Makes Schools Successful (Volume IV): Resources, Policies and Practices, PISA, OECD Publishing, Paris, http://dx.doi.org/10.1787/9789264201156-en.

OECD (2012), Recommendation of the Council on Principles for Public Governance of PublicPrivate Partnerships, OECD, https://www.oecd.org/governance/budgeting/PPPRecommendation.pdf (accessed on 19 December 2017).

OECD (2011), Taxation and Employment, OECD Tax Policy Studies, No. 21, OECD Publishing, Paris, http://dx.doi.org/10.1787/9789264120808-en.

OECD (2006), The Political Economy of Environmentally Related Taxes, OECD Publishing, Paris, http://dx.doi.org/10.1787/9789264025530-en. 
OECD (2005), Sustainable Development in OECD Countries: Getting the Policies Right, OECD

Publishing, Paris, http://dx.doi.org/10.1787/9789264016958-en.

OECD (2004), "Competition Policy in Subsidies and State Aid", OECD Journal: Competition

Law and Policy, Vol. 6/1, http://dx.doi.org/10.1787/clp-v6-art3-en.

OECD/KIPF (2014), The Distributional Effects of Consumption Taxes in OECD Countries, OECD Publishing, Paris, http://dx.doi.org/10.1787/9789264224520-en.

Oueslati, W. et al. (2016), "Exploring the Relationship between Environmentally Related Taxes and Inequality in Income Sources: An Empirical Cross-country Analysis", OECD Environment Working Papers, No. 100, OECD Publishing, Paris, http://dx.doi.org/10.1787/5jm3mbfzkrzp-en.

Phillips, P. and M. Loretan (1991), "Estimating Long-Run Economic Equilibria", The Review of Economic Studies, Vol. 58/3, pp. 407-436, http://dx.doi.org/10.2307/2298004.

Piketty, T. and E. Saez (2007), "How Progressive is the U.S. Federal Tax System? A Historical and International Perspective", Journal of Economic Perspectives, Vol. 21/1, pp. 3-24, http://dx.doi.org/10.1257/jep.21.1.3.

Pinault, L., A. van Donkelaar and R. Martin (2017), "Exposure to Fine Particulate Matter Air Pollution in Canada", Health Reports.

Randolph, W. (2006), "International Burdens of the Corporate Income Tax", Working Paper Series, Congressional Budget Office, Washington D C.

Saikkonen, P. (1991), "Asymptotically Efficient Estimation of Cointegration Regressions", Econometric Theory, Vol. 7/01, pp. 1-21, http://dx.doi.org/10.1017/S0266466600004217.

Sala-i-Martin, X., G. Doppelhofer and R. Miller (2004), "Determinants of Long-Term Growth: A Bayesian Averaging of Classical Estimates (BACE) Approach", American Economic Review, Vol. 94/4, pp. 813-835, http://dx.doi.org/10.1257/0002828042002570.

Seim, D. (2017), "Behavioral Responses to Wealth Taxes: Evidence from Sweden”, American Economic Journal: Economic Policy, Vol. 9/4, pp. 395-421, http://dx.doi.org/10.1257/pol.20150290.

Serret, Y. and N. Johnstone (2006), The Distributional Effects of Environmental Policy, Edward Elgar Pub./OECD, http://www.oecd.org/env/toolsevaluation/thedistributionaleffectsofenvironmentalpolicy.htm (accessed on 15 December 2017).

Slack, E. and R. Bird (2014), "The Political Economy of Property Tax Reform", OECD Working Papers on Fiscal Federalism, No. 18, OECD Publishing, Paris, http://dx.doi.org/10.1787/5jz5pzvzv6r7-en.

Smith, M. et al. (2017), "Capitalists in the Twenty-First Century", mimeo, https://eml.berkeley.edu/ yagan/Capitalists.pdf (accessed on 22 March 2018).

Stiglitz, J., A. Sen and J. Fitoussi (2009), Report of the Commission on the Measurement of Economic Performance and Social Progress, Commission on the Measurement of Economic Performance and Social Progress, Paris, http://www.stiglitz-sen-fitoussi.fr/en/index.htm.

Stock, J. et al. (1993), “A Simple Estimator of Cointegrating Vectors in Higher Order Integrated Systems", Econometrica, Vol. 61/4, pp. 783-820, https://econpapers.repec.org/article/ecmemetrp/v_3a61_3ay_3a1993_3ai_3a4_3ap_3a783$\underline{820 . h t m}$. 
Suárez Serrato, J. and O. Zidar (2016), "Who Benefits from State Corporate Tax Cuts? A Local Labor Markets Approach with Heterogeneous Firms", American Economic Review, Vol. 106/9, pp. 2582-2624, http://dx.doi.org/10.1257/aer.20141702.

Tanzi, V. (1995), Taxation in an Integrating World, Brookings Institution, https://www.abebooks.fr/9780815782988/Taxation-Integrating-World-National-Economies0815782985/plp (accessed on 15 December 2017).

White, A. (2007), “A Global Projection of Subjective Well-being: A Challenge to Positive Psychology?", Psychtalk 56, pp. 17-20, http://data360.org/pdf/20071219073602.A\%20Global\%20Projection $\% 20$ of $\% 20$ Subjective $\% 2$ 0Well-being.pdf.

World Health Organization (2001), Macroeconomics and Health: Investing in Health for Economic Development, WHO, http://www1.worldbank.org/publicsector/pe/PEAMMarch2005/CMHReport.pdf. 